\title{
Effects of lovastatin on breast cancer cells: a proteo-metabonomic study
}

\author{
Jelena Klawitter ${ }^{1 *}$, Touraj Shokati ${ }^{1}$, Vanessa Moll', Uwe Christians ${ }^{1}$, Jost Klawitter ${ }^{1,2}$
}

\begin{abstract}
Introduction: Statins are cholesterol-lowering drugs with pleiotropic activities including inhibition of isoprenylation and reduction of signals driving cell proliferation and survival responses.

Methods: In this study we evaluated the effects of lovastatin acid and lactone on breast cancer MDAMB231 and MDAMB468 cells using a combination of proteomic and metabonomic profiling techniques.

Results: Lovastatin inhibited proliferation of breast cancer cell lines. MDAMB231 cells were more sensitive to its effects, and in most cases lovastatin acid showed more potency towards the manipulation of protein expression than lovastatin lactone. Increased expression of Rho inhibitor GDI-2 stabilized the non-active Ras homolog gene family member A (RhoA) leading to a decreased expression of its active, membrane-bound form. Its downstream targets cofilin, CDC42 and G3BP1 are members of the GTPase family affected by lovastatin. Our data indicated that lovastatin modulated the E2F1-pathway through the regulation of expression of prohibitin and retinoblastoma (Rb). This subsequently leads to changes of E2F-downstream targets minichromosome maintenance protein 7 (MCM7) and MutS homolog 2 (MSH2). Lovastatin also regulated the AKT-signaling pathway. Increased phosphatase and tensin homolog (PTEN) and decreased DJ-1 expression lead to a down-regulation of the active pAkt. Lovastatin's involvement in the AKT-signaling pathway was confirmed by an upregulation of its downstream target, tumor progressor NDRG1. Metabolic consequences to lovastatin exposure included suppression of glycolytic and Krebs cycle activity, and lipid biosynthesis.
\end{abstract}

Conclusions: The combination of proteomics and metabonomics enabled us to identify several key targets essential to the antitumor activity of lovastatin. Our results imply that lovastatin has the potential to reduce the growth of breast cancer cells.

\section{Introduction}

Breast cancer is the second leading cause of cancer death in women. There are currently no effective therapies for advanced breast cancer, with treatment primarily aimed at palliation of symptoms and improvement of overall survival. Healthy women at high risk of breast cancer are the focus of prevention, whereas current chemotherapy targets women after a positive diagnosis. Prevention in at risk, but healthy, women requires efficacious drugs with a good long-term safety and tolerability profile. Statins fit these criteria [1-6].

Statins are competitive inhibitors of 3-hydroxy-3methylglutaryl coenzyme reductase (HMG-CoA). They

\footnotetext{
*Correspondence: Jelena.Klawitter@ucdenver.edu

'Department of Anesthesiology, Clinical Research and Development,

University of Colorado Denver, 12401 East 17th Avenue, Aurora, CO, 80045,
} USA

() 2010 Klawitter et al.; licensee BioMed Central Ltd. This is an open access article distributed under the terms of the Creative Commons Attribution License (http://creativecommons.org/licenses/by/2.0), which permits unrestricted use, distribution, and reproduction in any medium, provided the original work is properly cited. reduce cholesterol synthesis by blocking the conversion of HMG-CoA to mevalonate [7]. The end products of the mevalonate pathway are required for a number of essential cellular functions. The end products include: sterols, involved in membrane integrity and steroid production; ubiquinone (coenzyme Q), involved in electron transport and cell respiration; farnesyl and geranylgeranyl isoprenoids, involved in covalent binding of proteins to membranes; dolichol, which is required for glycoprotein synthesis; and isopentenyladenine, essential for certain tRNA functions and protein synthesis $[8,9]$.

HMG-CoA reductase inhibitors have been shown to inhibit cellular proliferation and induce apoptosis and necrosis in several experimental settings including that of breast cancer, thus making them potential anticancer agents [10-12]. Induction and enhancement of reactive oxygen species (ROS) formation has been explored as a

\section{Biomed Central}


possible cause of cytotoxicity of statins in breast cancer cells [13]. Stimulation of nitric oxide synthase (iNOS) and the subsequent increase in nitric oxide (NO) levels may also play a role in the pro-apoptotic and anti-proliferative effects of statins on breast cancer cells [14]. Several cell signaling pathways seem to be involved in the inhibition of cell proliferation and statin-induced cancer cell death, including FAK/ERK pathways [15], increased expression of p21, p27 and activated caspase-3, and changes in the expression of several cyclin-dependent kinases [16].

Recent clinical data show that statins may influence the phenotype of breast tumors, suggesting a new potential strategy for breast cancer prevention, that of combining statins with agents that prevent estrogen receptor (ER)-positive cancer (tamoxifen, aromatase inhibitors) [1]. Another study suggested statin treatment following breast cancer diagnosis decreases the risk of recurrence, and a further decline in correlation to the duration of statin use [2]. Lovastatin is orally administered to patients in its lactone form. However, after absorption, lovastatin is quickly converted into its open acid form and, as with most statins, lovastatin is present in plasma as the active acid that is responsible for HMG-CoA inhibition and two orders of magnitude more lipophilic lactone. As both forms have distinct physicochemical properties and potentially different mechanisms of action, both are studied here.

In order to gain more insight into the anticancer activity and mechanism of action of statins in breast cancer cells, our study employed a combination of proteomics-based and nuclear magnetic resonance (NMR)based metabonomics techniques. We identified new key targets of lovastatin, and revealed involvement of several regulatory cellular pathways in the cytotoxic effects of lovastatin on breast cancer cell lines.

\section{Materials and methods Reagents}

Tris- $\mathrm{HCl}$, sodium chloride, EDTA, NP-40, sodium deoxycholate, urea, thiourea, SDS, $20 \%$ glycerol, methanol, acetic acid and iodacetamide were purchased from Sigma-Aldrich (Allentown, PA, USA). Protease and phosphate inhibitors were from Pierce Biotechnology (Rockford, IL, USA); immobilized pH gradient (IPG) buffer $\mathrm{pH} 3$ to 11 was from GE Healthcare (Piscataway, NJ, USA) and dithiothreitol (DTT) was from USB (Cleveland, $\mathrm{OH}, \mathrm{USA}$ ). Lovastatin (in its lactone and hydroxy acid form) was purchased from Toronto Research Chemicals (North York, Ontario, Canada). 3(4,5-dimethylthiazol-2-Yl)-2,5-diphenyltetrazolium bromide (MTT) cell growth assay kits were from Millipore (Billerica, MA, USA).

\section{Cell culture and treatments}

MDAMB468 and MDAMB231 cell lines were from American Type Culture Collection (ATCC) and propagated according to the instructions provided. Both cell lines are ER negative, and for this study relevant differences were that MDAMB468 cells lack expression of retinoblastoma $(\mathrm{Rb})$, phosphatase and tensin homolog (PTEN) and steroid and xenobiotic receptor (SXR) proteins.

For proteomics studies, cells were treated for 48 hours with $8 \mu \mathrm{g} / \mathrm{mL}$ lovastatin lactone or hydroxy acid. MTT assays were performed prior to proteomics studies for IC50 determination. To investigate the effects of isoprenoid intermediates of the cholesterol biosynthetic pathway, in particular geranylgeranyl diphosphate (GGPP), farnesyl pyrophosphate (FPP) and mevalonic acid on the proliferation of cells treated with lovastatin, MDAMB231 and MDAMB468 cells were treated with $2 \mu \mathrm{g} / \mathrm{mL}, 4 \mu \mathrm{g} / \mathrm{mL}$ and $8 \mu \mathrm{g} / \mathrm{mL}$ lovastatin acid or lactone and were 'rescued' by addition of $10 \mu \mathrm{M}$ GGPP, $100 \mu \mathrm{M}$ mevalonic acid or $10 \mu \mathrm{M}$ FPP.

\section{MTT assay}

The cells were cultured in 96-well plates. Treatment occurred with lovastatin in its lactone or acid form or with a combination of lovastatin with GGPP, FPP or mevalonic acid for 48 hours. During the last four hours, $0.02 \%$ MTT solution was added and the reaction was stopped with isopropanol and $5 \%$ acetic acid. The production of purple formazan in cells treated with an agent was measured relative to the production in control cells and dose-response curves were generated with a Perkin Elmer (Waltham, MA, USA) ELISA plate reader at $525 \mathrm{~nm}$.

$\mathrm{IC}_{50}$ values were estimated using the Prism software (GraphPad Software Inc., Version 4.0, San Diego, CA, USA).

\section{Two-dimensional gel electrophoresis}

For proteomics studies, cells were washed twice with ice-cold PBS followed by a collection in modified RIPA lysis buffer (50 mM Tris- $\mathrm{HCl}, \mathrm{pH}$ 7.4; $150 \mathrm{mM} \mathrm{NaCl} ; 1$ mM EDTA; $1 \%$ NP-40 (v/v); 0.25\% sodium deoxycholate $(\mathrm{v} / \mathrm{v})$; protease and phosphatase inhibitor cocktail). After complete solubilization, cell extracts were subjected to purification using a 2-D clean-up kit (GE Healthcare, Piscataway, NJ, USA) in accordance with the manufacturer's instructions. The final solubilization was performed in chaotropic lysis buffer containing $7 \mathrm{M}$ urea, 1 $\mathrm{M}$ thiourea, $50 \mathrm{mM}$ DTT, $0.4 \%$ IPG buffer $\mathrm{pH} 4$ to 7 , protease and phosphatase inhibitors. The protein concentrations were determined using a BioRad Bradford protein assay kit (BioRad, Hercules, CA, USA). Samples 
of $300 \mu \mathrm{g}$ cell extract (in $200 \mu \mathrm{L}$ ) were loaded onto Immobiline DryStrips $(11 \mathrm{~cm}, \mathrm{pH} 3$ to 8 , GE Healthcare, Piscataway, NJ, USA). Isoelectric focusing was performed on a Protean IEF cell (Biorad, Hercules, CA, USA) with the following voltage program: rehydration: $50 \mathrm{~V}, 12$ hours; 1000 V, 2 hours (gradient); $6000 \mathrm{~V}, 4$ hours (gradient); $8000 \mathrm{~V}$, 6 hours (rapid), maximal current 50 uA per strip. Strips were equilibrated in $20 \mathrm{~mL}$ rehydration buffer ( $6 \mathrm{M}$ urea, $50 \mathrm{mM}$ Tris- $\mathrm{HCl} \mathrm{pH} 8.8,2 \% \mathrm{SDS}, 20 \% \mathrm{v} / \mathrm{v}$ glycerol) containing $10 \mathrm{mg} / \mathrm{mL}$ DTT and $25 \mathrm{mg} / \mathrm{mL}$ iodacetamide for 20 minutes each. The second dimension was performed using a Mini-Protean Dodeca chamber (Biorad, Hercules, CA, USA) on 10.5 to $14 \%$ Criterion Tris- $\mathrm{HCl}$ gels (IPG + 1 well, $11 \mathrm{~cm}$, Biorad, Hercules, CA, USA). Gels were washed with nanopure water and with Biosafe CoomassieBlue Stain (Biorad, Hercules, CA, USA) or fixed for one hour in $50 \%$ methanol, $10 \%$ acetic acid and stained with Sypro Ruby protein gels stain (Invitrogen, Carlsbad, CA, USA) overnight. Prior to imaging Coomassie-Blue stained gels were washed in nanopure water for up to 24 hours and imaged on LabScan Image Scanner (GE Healthcare, Piscataway, NJ, USA) with 900 dpi. Sypro Ruby-stained gels were washed twice in 10\% methanol and 7\% acetic acid for one hour each and imaged on a Typhoon 8600 imager (Amersham Pharmacia Biotech, Piscataway, NJ, USA) with $532 \mathrm{~nm}$ laser wavelength.

Gel image analysis was carried out using the ImageMaster 2D Platinum II software version 5.0 (GE Healthcare, Piscataway, NJ, USA). The spot auto-detect function was used for all group comparisons using identical parameters. Groups were matched automatically and corrected manually if necessary. Differences in protein expression were identified using the relative volume (\% Vol) option of the software. This option allows the data to be independent of experimental variations between gels caused by differences in loading or staining. Relative volume was calculated as follows $[17,18]$ :

$\therefore$ Vol $=\frac{\text { Vol }}{\sum_{\mathrm{S}=1}^{\mathrm{n}} \mathrm{Vol}_{\mathrm{S}}} \times 100$ with $\mathrm{Vol}_{\mathrm{s}}$ being the volume of spot $s$ in a gel containing $n$ spots.

Raw spot values were normalized using the software's ratio option according to the following equation [17-19]:

$$
\text { Ratio }=\frac{\text { spotvalues }_{\mathbf{S}}}{\text { centraltendency }} \text { with central tendency being }
$$

the mean of spot $s$.

Changes in average volume larger than $\pm 40 \%$ of the average spot volume and the significance level of $P<$ 0.05 (control vs. treated group) was the criterion used for excision. Four replicates were used for each control, lovastatin lactone or acid treatment, respectively.

\section{In-gel digestion}

Proteins from excited gels spots were digested using a modification of the method by Havlis [20]. Briefly, spots were destained with acetonitrile and $100 \mathrm{mM}$ ammonium bicarbonate $(50 / 50 \mathrm{v} / \mathrm{v})$, contracted with $100 \%$ acetonitrile and then vacuum dried. Spots were rehydrated with $50 \mu \mathrm{g} / \mathrm{ml}$ trypsin (sequencing grade II, Worthington, Lakewood, NJ, USA) and incubated for 10 minutes on ice. Excess liquid was removed and $50 \mathrm{mM}$ ammonium bicarbonate added prior to overnight incubation at $37^{\circ} \mathrm{C}$. The supernatants were collected and pooled with two additional extracts using $1 \%$ formic acid with $30 \%$ acetonitrile. Pooled extracts were vacuum concentrated to approximately $10 \mu \mathrm{L}$ and stored at $-80^{\circ} \mathrm{C}$ until mass spectrometry analysis.

\section{LC-MS/MS analysis of tryptic digests}

The analysis of tryptic digests was performed using a 4000 QTRAP liquid chromatography (LC) mass spectrometry (MS)/MS system (Applied Biosystems, Foster City, CA, USA) equipped with a Dionex Ultimate 3000 nanoLC system (Dionex Corporation, Sunnyvale, CA, USA).

Peptides were loaded onto an enrichment column (C18PM, LC packings $0.3 \mathrm{~mm}$ ID) with $3 \%$ acetonitrile (ACN) and $0.05 \%$ trifluoroacetic acid (TFA) at a flow rate of $4 \mu \mathrm{L} / \mathrm{min}$. After activation of a switching valve, the peptide mixture was back-flushed from the enrichment onto the analytical column (Zorbax 300SB C18, 3.5 um, $150 \times 75$, Agilent Technologies, Palo Alto, CA, USA) using a gradient. Solvent A was $0.1 \%$ formic acid and solvent $\mathrm{B}$ was $80 \% \mathrm{CAN}$ and $0.1 \%$ formic acid. The flow rate was $400 \mathrm{~nL} / \mathrm{min}$. Buffer B was increased from $5 \%$ to $8 \%$ in one minute and then from $8 \%$ to $45 \%$ over 39 minutes. Finally, solvent B was increased to and held at $80 \%$ for the next five minutes, after which the settings were returned to initial conditions. Spectra were collected over an $\mathrm{m} / \mathrm{z}$ range of 350 to $2200 \mathrm{Da}$. Three MS/ MS spectra were collected for the three most abundant $m / z$ values. Then those were excluded from analysis for one minutes and the next three most abundant $\mathrm{m} / z$ values were selected for fragmentation.

\section{Protein identification using database searching}

Proteins were identified by searching the databases of the NCBInr (National Center for Biotechnology Information, non-redundant) and SwissProt (Swiss Institute of Bioinformatics) using ProteinPilot 2.0 with paragorn algorithm (Applied Biosystems, Foster City, CA, USA) software. Parameters used in the database search were as follows: biological modifications; fixed modification: iodacetamide alkylation of Cys; detected protein threshold: more than 1 (90\%); thorough ID.

\section{Cell extraction for nuclear magnetic resonance spectroscopy}

For NMR experiments, the cells were incubated with 5 $\mathrm{mmol} / \mathrm{L}\left(1-{ }^{13} \mathrm{C}\right)$ glucose (Cambridge Isotope Laboratories, 
Andover, MA, USA) for the last five hours prior to the perchloric acid (PCA) extraction. All cell extractions were performed using a previously published PCA extraction protocol that allowed for separation of water-soluble and lipid fractions [21]. Lyophilized water-soluble cell extracts were re-dissolved in $0.5 \mathrm{~mL}$ of deuterium oxide, centrifuged and the supernatants neutralized to $\mathrm{pH} 7.2$ in order to allow for precise chemical shift assignments. Lipid fractions were re-dissolved in a $1 \mathrm{~mL} \mathrm{CD} \mathrm{CD}_{3} \mathrm{OD} / \mathrm{CDCl}_{3}$ mixture (1:2).

\section{NMR spectroscopy}

High-resolution ${ }^{1} \mathrm{H}$ and ${ }^{13} \mathrm{C}$-NMR experiments were performed using a Varian INOVA NMR $500 \mathrm{MHz}$ spectrometer equipped with a $5 \mathrm{~mm}$ HCN PFG probe (Varian, Palo Alto, CA, USA). For ${ }^{1} \mathrm{H}-\mathrm{NMR}$ analysis of water-soluble extracts we have used fully relaxed spectra with a standard water presaturation pulse program, whereas for analysis of lipids no presaturation pulse was used. Spectra were obtained at $12 \mathrm{ppm}$ spectral width (10 ppm for lipids), $32 \mathrm{~K}$ data arrays, and 64 scans with 90-degree pulses applied every 14.8 seconds. The pool size of metabolites was determined based on fully relaxed ${ }^{1} \mathrm{H}-\mathrm{NMR}$ spectra of extracts using trimethylsilyl propionic-2,2,3,3,- $\mathrm{d}_{4}$ acid (TSP) as an external standard and chemical shift reference $(0 \mathrm{ppm})$. The absolute concentrations of each metabolite [metabolite] were determined and normalized according to cell wet weight, as previously described [22-24] and calculated using the following equation:

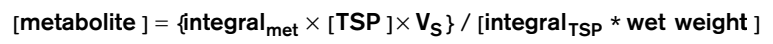

where integral ${ }_{\text {met }}$ is integral of respective metabolite signal divided by the number of protons; integral ${ }_{\mathrm{TSP}}$ is integral of TSP signal divided by the number of protons; [TSP] is TSP nominal concentration; $V_{S}$ is sample volume; wet weight is sample weight.

${ }^{13} \mathrm{C}$-NMR spectra with proton decoupling (composite pulse decoupling) were recorded using the C3-lactate peak at $21 \mathrm{ppm}$ as chemical shift reference (spectral width was $150 \mathrm{ppm}, 16 \mathrm{~K}$ data arrays, with $20 \mathrm{~K}$ scans applied every three seconds). For quantification of absolute concentrations of ${ }^{13} \mathrm{C}$ metabolites, calculations were made according to $[25,26]$. The ${ }^{13} \mathrm{C}$ enrichments in C3-lactate were determined by the heteronuclear spin-coupling pattern in ${ }^{1} \mathrm{H}-\mathrm{NMR}$ spectra as follows:

$$
{ }^{13} \mathrm{C}-\text { enrichment }=\left[\operatorname{area}\left({ }^{1} \mathrm{H}-{ }^{13} \mathrm{C}\right) \times 100\right] /\left[\operatorname{area}\left({ }^{1} \mathrm{H}-{ }^{12} \mathrm{C}\right)+\operatorname{area}\left({ }^{1} \mathrm{H}-{ }^{13} \mathrm{C}\right)\right]
$$

where the sum (area $\left[{ }^{1} \mathrm{H}_{-}{ }^{12} \mathrm{C}\right]+$ area $\left[{ }^{1} \mathrm{H}_{-}{ }^{13} \mathrm{C}\right]$ ) is equivalent to the pool size of lactate. The values were corrected for $1.1 \%$ natural abundance ${ }^{13} \mathrm{C} .{ }^{13} \mathrm{C}$-enrichments in individual carbons of amino acids were derived from ${ }^{13} \mathrm{C}$-NMR spectra using the known ${ }^{13} \mathrm{C}$-enrichment in lactate:

$$
\left.E_{\text {Met }}(\%)=\left[A_{\text {Met }}-A_{n a .}(\text { Met })\right] / A_{n a .}(\text { Met })\right] \times 1.1
$$

where $A_{M e t}$ represents ${ }^{13} \mathrm{C}$ carbon peak area of the metabolite, $A_{\text {n.a. }}$ is its natural abundance signal intensity, and 1.1 is the percentage factor of the ${ }^{13} \mathrm{C}$-isotope. The natural abundance of ${ }^{13} \mathrm{C}$, contributing to the total intensity $\mathrm{A}_{\text {n.a. }}(\mathrm{Met})$, was determined using the known ${ }^{13} \mathrm{C}$-enrichment and natural abundance of lactate and correction for the pool size:

$$
A_{\text {n.a }}(\text { Met })=\left\{A_{\text {Lac }} \times[\text { Met }]\right\} /\left\{\left(E_{\text {Lac }}+1\right) \times[\text { Lac }]\right\}
$$

$\mathrm{A}_{\mathrm{Lac}}$ represents the carbon peak area of lactate, [Lac] or [Met] are the pool sizes of lactate or metabolite of interest, respectively, and $\mathrm{E}_{\mathrm{Lac}}$ is the percentage ${ }^{13} \mathrm{C}$ enrichment in lactate. The ${ }^{13} \mathrm{C}$ signal intensities were corrected for nuclear Overhauser enhancement effects by comparison with the standard mixture of amino acids.

The absolute amount of ${ }^{13} \mathrm{C}$ in specified carbon positions is the product of the pool size multiplied by the fractional ${ }^{13} \mathrm{C}$-enrichment.

\section{Western blot analysis}

Western blot analysis was carried out to validate proteomics 'hits'. Aliquots of frozen extracts were loaded onto Biorad 4 to $12 \%$ Bis-Tris Criterion gels and proteins separated using a Biorad Criterion cell electrophoresis system (BioRad, Hercules, CA, USA) operating for approximately two hours at $120 \mathrm{~V}$ and then transferred (200 mA, 5 hours) from the gel to an Immobilon-P membrane (Millipore Corporation, Billerica, MA, USA). Membranes were incubated overnight at $4^{\circ} \mathrm{C}$ with the primary antibody following blocking with $5 \%$ milk/BSA in PBS-Tween buffer. Antibodies used in this study included: proliferating cell nuclear antigen (PCNA), prohibitin, E2F-1, RhoGDI, Ras homolog gene family member A (RhoA), pRb, cell division cycle 42 (CDC42), PTEN (Cell Signaling Technology, Inc., Danvers, MA, USA); high-mobility group protein B1 (HMGB1), N-myc downstream regulated gene 1 (NDRG1), DJ-1, pAkt (Abcam, Cambridge, MA, USA); MutS homolog 2 (MSH2), phospho-GTPase activating protein binding protein 1 (G3BP1), pG3BP1 (GenScript, Piscataway, NJ, USA); minichromosome maintenance protein 7 (MCM7) (Biolegend, San Diego, CA, USA). After the membranes were washed three times, the secondary antibody (horseradish peroxidase (various hosts), Pierce, Rockford, IL, USA) was applied for three hours at room temperature. Membranes were subsequently treated with Pierce SuperSignal ${ }^{\circ}$ West Pico Solution (Pierce, Rockford, IL, USA) in accordance with the method 
described by the manufacturer's protocol. A UVP BioImaging Systems UV detector (BioImaging Systems, Upland, CA, USA) was used to detect the horseradish peroxidase reaction on the membrane. Densitometry data were normalized by the amount of $\beta$-actin.

\section{Statistical analysis}

All numerical data is presented as mean \pm standard deviation from replicate experiments. Student's t test, or when applicable one-way analysis of variance (ANOVA) were used to determine differences between groups. Tukey's test was used as a post-hoc test in combination with ANOVA to test for significances among groups. The significance level was set at $\mathrm{p}<0.05$ for all tests (SigmaPlot-version 11.0, Systat Software, Point Richmond, CA, USA) and PASW version 18.0 (SPSS Inc., Chicago, IL, USA).

\section{Results}

\section{Lovastatin inhibits cell proliferation}

Lovastatin induces inhibition of cell proliferation in MDAMB468 and MDAMB231 cells (Figure 1). The lovastatin hydroxy acid form was slightly more effective in both cell lines with a half maximum inhibition concentration $\left(\mathrm{IC}_{50}\right)$ of $8 \mu \mathrm{g} / \mathrm{mL}$ in MDAMB468 and $5 \mu \mathrm{g} /$ $\mathrm{mL}$ in MDAMB231 cells, whereas the $\mathrm{IC}_{50}$ values for lovastatin lactone were $9 \mu \mathrm{g} / \mathrm{mL}$ and $7 \mu \mathrm{g} / \mathrm{mL}$, respectively. All subsequent experiments were carried out using $8 \mu \mathrm{g} / \mathrm{mL}$ lovastatin in its lactone or acid form.

In rescue experiments, when cells were co-incubated with lovastatin and GGPP, FPP or mevalonate, only mevalonate and GGPP were able to fully rescue cells from the anti-proliferative effect of lovastatin, whereas FPP could only achieve a partial rescue. Upon GGPP and mevalonate co-exposure with $8 \mu \mathrm{g} / \mathrm{mL}$ lovastatin (acid or lactone), cells regained 92 to $98 \%$ of the proliferation rate of control cells, whereas only $67 \%$ was regained with the co-administration of lovastatin and FPP.

Two-dimensional gel electrophoresis and MS analysis of lovastatin-induced changes in the protein expression of breast cancer cells

In order to obtain a comprehensive view of changes in the protein synthesis in response to lovastatin treatment, proteome analyses using two-dimensional gel electrophoresis were performed on MDAMB468 and MDAMB231 breast cancer cell lines (Figure 2). Both forms of lovastatin (lactone and hydroxy acid form with $8 \mu \mathrm{g} / \mathrm{mL}$ for 48 hours) were used for cell treatment.

\section{Functional classification of identified proteins}

Each identified protein was assigned a functional classification based on the gene ontology annotation in the
Database for Annotation, Visualization, and Integrated Discovery (DAVID). The DAVID annotation tool was used for functional clustering and pathway mapping of identified protein hits. A comparison between the expressional changes of spots in the lactone or hydroxy acid group revealed that both chemical forms of lovastatin followed the same directional change through an increase or decrease in the relative protein abundance. For this reason, we combined the treatment groups and these combined protein hits were then subjected to DAVID annotation tool analysis.

Seventy-four proteins were identified as significantly changed upon treatment with $8 \mu \mathrm{g} / \mathrm{mL}$ lovastatin (lactone or acid form) in MDAMB231 cells, and 42 such proteins were identified in MDAM468 cells (Table 1). Despite the stronger response of MDAMB231 cells, impact by lovastatin on the biological processes was similar in both cell lines. For example, the addition of lovastatin not only influenced the major metabolic cellular pathways, such as glycolysis or pentose-phosphate shunt, it also changed expression of proteins involved in the regulation of apoptosis, stress response, cell differentiation and actin-filament morphogenesis. Furthermore, lovastatin lactone and acid exposure-induced changes in cell cycle regulatory proteins and small GTPases mediated signal transduction members.

\section{Small GTPases mediated signal transduction}

Small GTPase family members, some of which are known to modulate Ras protein signal transduction, have been described in the literature as major targets of statins other than HMG-CoA reductase [27,28].

Our proteomics data revealed a decrease in total expression of RhoA (Table 1). In addition to the total expression, a western blot analysis on membrane-bound, geranylgeranylated RhoA in MDAMB231 cells was performed and it was found that lovastatin acid caused a significant decrease in the expression of this activated RhoA form, and that only a slight decrease was caused by the lactone (Figure 3). Our data also showed that the expression of GDP dissociation inhibitor 2 (GDI-2), a protein stabilizing the inactive RhoA form, experienced a significant increase and was more pronounced in MDAMB231 than in MDAMB468 cells (Figure 3). Lovastatin also induced downregulation of unmodified and G3BP1 (Table 1, Figures 2a and 3; down-regulation of phospho-G3BP1 only with lovastatin lactone) and cofilin $1 / 2$ proteins (Figure $2 \mathrm{a}$ ), and an overexpression of CDC42 protein (Figure 3 ).

\section{Inhibition of cell proliferation and cell-cycle activity}

Several proteins present in breast cancer cells that are involved in regulation of cell proliferation and cell-cycle activity were significantly altered when exposed to 


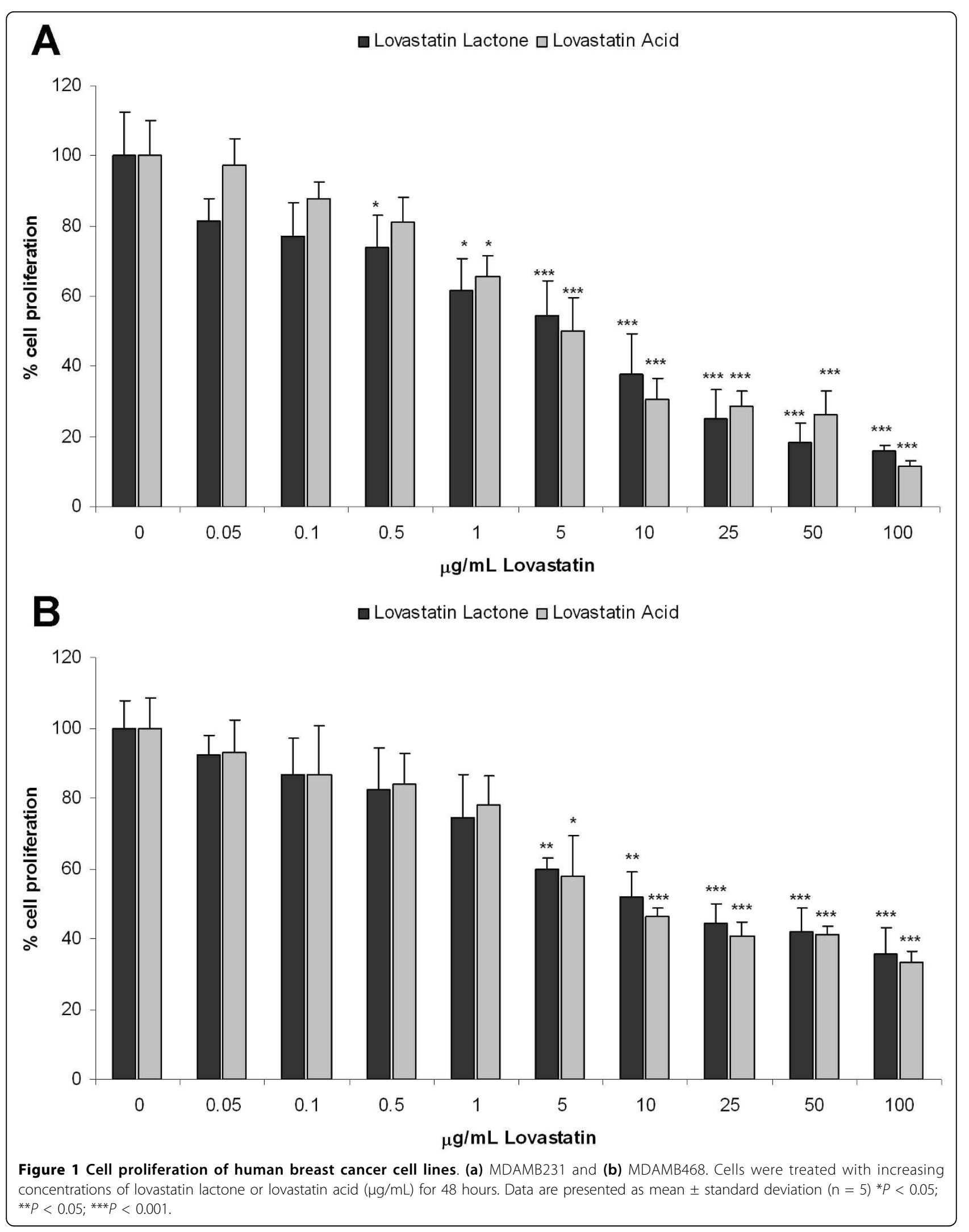




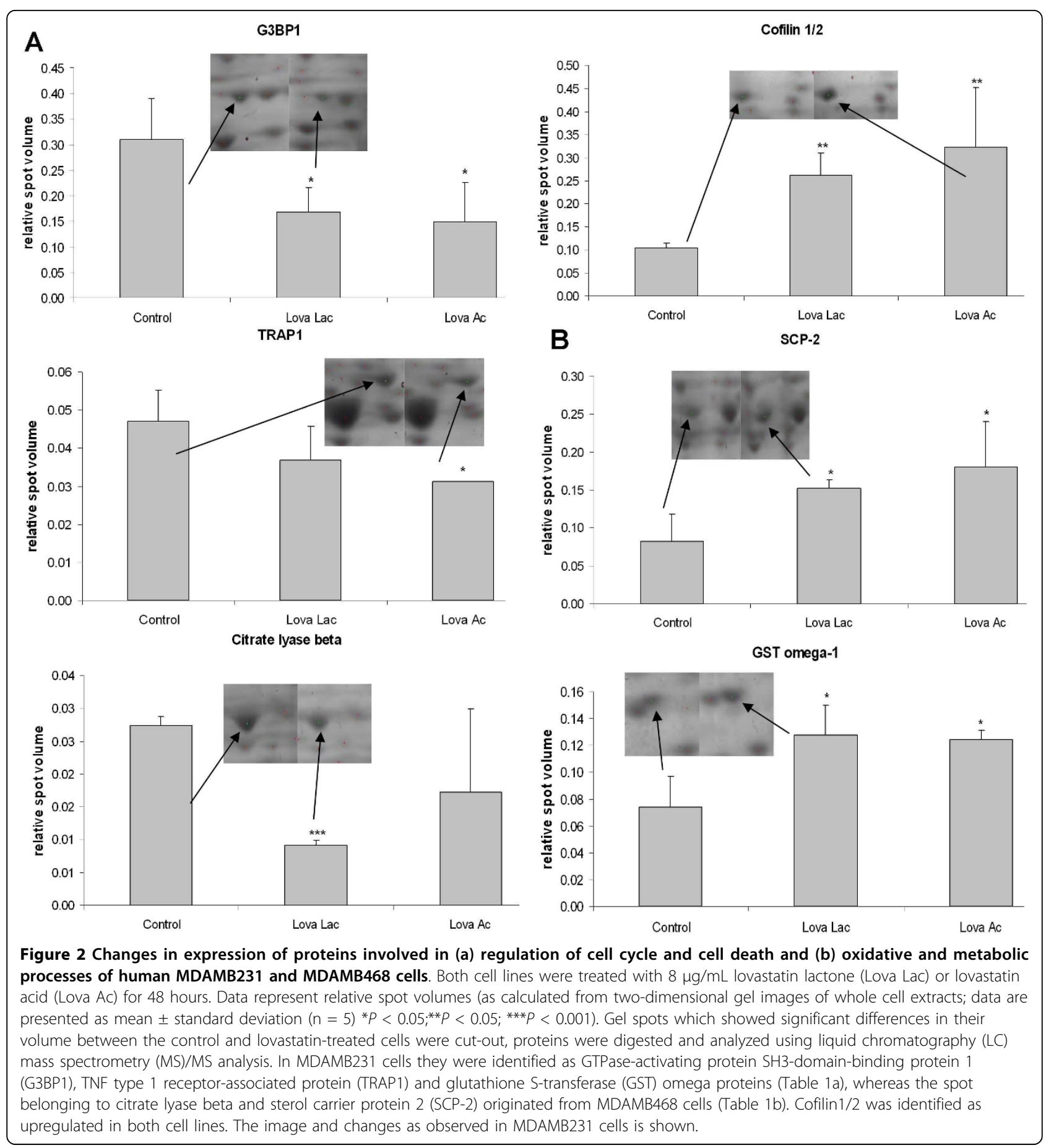

lovastatin. Changes in the expression of the two E2F activity related cell-cycle regulatory proteins prohibitin and MCM7, were also detected. Although the expression of prohibitin increased nearly two-fold (Table 1 and Figure 4), the expression of MCM7, an essential component of the replication helicase complex [29], decreased to $28 \%$ of control (Table 1 and Figure 3). Lovastatin-induced DNA damage also had an impact on damage repair regulating pathways. We observed a downregulation of a representative member of DNA-mismatch repair (MMR) systems, MSH2 (Figure 4 and Table 1). Expression of PCNA is downregulated by both forms of lovastatin in MDAMB231 cells, with a stronger reduction in presence of the lactone form (Table 1 and Figure 5). 
Table 1 Overview of proteins showing significant differences $(P<0.05)$ between control and treated MDAMB468 and MDAMB231 breast cancer cells

\begin{tabular}{|c|c|c|}
\hline MDAMB468 cells & Control vs. lactone & Control vs. acid \\
\hline 14-3-3 beta & 3.51 & 1.93 \\
\hline 14-3-3 zeta/theta & 1.61 & 1.48 \\
\hline 17-beta hydroxysteroid dehydrogenase & 0.62 & 0.47 \\
\hline 6-phosphogluconolactonase & 1.56 & 1.5 \\
\hline alpha enolase & 1.89 & 1.37 \\
\hline alpha glucosidase subunit alpha isoform 3 & 0.64 & 0.4 \\
\hline ATPase, $\mathrm{H}+$ transporting, lysosomal $70 \mathrm{kDa}$ V1 subunit A & 0.30 & 0.31 \\
\hline ATP citrate lyase beta, mitochondrial & 0.33 & 0.63 \\
\hline Carbonyl reductase $[\mathrm{NADPH}] 3$ & 3.00 & 1.56 \\
\hline Chaperonin containing TCP1, subunit $6 \mathrm{~A}$ & 1.34 & 1.98 \\
\hline chloride intracellular channel 1 & 1.2 & 2.12 \\
\hline cofilin $1 / 2$ & 0.60 & 0.65 \\
\hline D3-phosphoglycerate dehydrogenase & 0.75 & 0.16 \\
\hline DJ-1 & 0.54 & 0.45 \\
\hline EEF1 delta & 0.68 & 0.4 \\
\hline ER-60 protein & 2.18 & 1.56 \\
\hline eukaryotic initiation factor $4 \mathrm{~A}-\|$ & 0.35 & 0.63 \\
\hline eukaryotic translation initiation factor 3 subunit $\mathrm{H}$ & 0.71 & 0.49 \\
\hline eukaryotic translation initiation factor 6 & 4.76 & 1.57 \\
\hline Ezrin & 2.10 & 4.00 \\
\hline gelsolin precursor & 2.73 & 1.54 \\
\hline glutamate receptor GRIA3 & 0.24 & 0.63 \\
\hline glycyl-tRNA synthetase & 0.40 & 0.33 \\
\hline heat shock cognate $71 \mathrm{kDa}$ protein & 0.20 & 0.36 \\
\hline IMMT (mitochondrial inner membrane protein) & 3.44 & 2.32 \\
\hline lamin $A / C$, isoform CRA_C & 0.41 & 0.47 \\
\hline MAPRE1 protein & 0.86 & 0.4 \\
\hline multidrug resistance-associated protein MGr1-Ag & 0.52 & 0.74 \\
\hline $\mathrm{NADH}$ dehydrogenase Fe-S protein 1, $75 \mathrm{kDa}$ & 0.56 & 0.35 \\
\hline nucleoside phosphorylase & 1.95 & 1.31 \\
\hline protein disulfide isomerase associated 6 & 0.85 & 0.41 \\
\hline protein disulfide isomerase ER-60 & 2.13 & 1.25 \\
\hline RAB8b, member RAS oncogene family & 3.16 & 1.48 \\
\hline RAVER-1 protein & 2.17 & 1.60 \\
\hline splicing factor, arginine/serine-rich 1 & 0.24 & 0.71 \\
\hline sterol carrier protein $\mathrm{X} / 2$ & 0.45 & 0.52 \\
\hline $\begin{array}{l}\text { stress-70 protein, mitochondrial precursor } \\
\text { (observed pl 5.9; theoretical pl 5.9) }\end{array}$ & 0.65 & 0.57 \\
\hline $\begin{array}{l}\text { stress-70 protein, mitochondrial precursor } \\
\text { (observed pl 5.6; theoretical pl 5.9) }\end{array}$ & 0.59 & 0.42 \\
\hline succinate dehydrogenase [ubiquinone] flavoprotein subunit & 0.59 & 0.3 \\
\hline $\begin{array}{l}\text { triosephosphate isomerase } \\
\text { (pl observed 6.7; theoretical pl 6.5) }\end{array}$ & 0.70 & 0.64 \\
\hline thioredoxin domain-containing protein 12 & 0.64 & 0.7 \\
\hline RhoA precursor & 0.65 & 0.6 \\
\hline \multicolumn{3}{|l|}{ MDAMB231 cells } \\
\hline 3-hydroxyisobutyrate dehydrogenase, mitochondrial & 0.64 & 0.73 \\
\hline aldose reductase & 1.64 & 1.40 \\
\hline alpha enolase & 0.28 & absent \\
\hline $\begin{array}{l}\text { annexin A1 } \\
\text { (observed pl 6.6; theoretical pl 6.6) }\end{array}$ & 1.67 & 1.42 \\
\hline
\end{tabular}


Table 1: Overview of proteins showing significant differences $(P<0.05)$ between control and treated MDAMB468 and MDAMB231 breast cancer cells (Continued)

annexin $\mathrm{A} 1$

1.24

3.08

(observed pl 6.4; theoretical pl 6.6)

annexin A4

cathepsin D precursor

cell division cycle protein 42

chloride intracellular channel protein 1

chloride intracellular channel protein 1

(observed pl 5.3; theoretical pl 5.1)

Cleavage stimulation factor $64 \mathrm{kDa}$ subunit

cofilin $1 / 2$

complement component $1 \mathrm{Q}$

subcomponent-binding protein, mitochondrial

Cytochrome b-c1 complex subunit 1, mitochondrial

Cytochrome c-type heme lyase

dihydrolipoamide S-acetyltransferase, component of PDH complex

DJ-1

elongation factor 1-delta

endoplasmic reticulum protein ERp29 precursor

eukaryotic translation initiation factor 3 subunit I

Ezrin

GDP dissociation inhibitor 2

gelsolin precursor (identified in 3 spots as fragment)

glutathione S-transferase P

glutathione S-transferase omega-1

glycyl-tRNA synthetase

GrpE protein homolog 1, mitochondrial precursor

heat shock protein 27

heterogeneous nuclear ribonucleoprotein $\mathrm{F}$

heterogeneous nuclear ribonucleoprotein $\mathrm{H}$

heterogeneous nuclear ribonucleoprotein $\mathrm{K}$

heterogeneous nuclear ribonucleoproteins $\mathrm{C} 1 / \mathrm{C} 2$

high mobility group protein $B$

interferon-induced GTP-binding protein Mx2

Ku70 antigen

lactoyl-glutathione lyase

lamin-A/C

LIM and SH3 domain protein 1

macrophage-capping protein (identified in two spots)

moesin

MutS homolog 2

Muts homolog 2

nucleophosmin

peroxiredoxin 3

plexin-D1 precursor

pre-mRNA-processing factor 19

prohibitin

proliferating cell nuclear antigen 
Table 1: Overview of proteins showing significant differences $(P<0.05)$ between control and treated MDAMB468 and MDAMB231 breast cancer cells (Continued)

putative ATP-dependent Clp protease

0.59

0.76

proteolytic subunit, mitochondrial

Ran-specific GTPase-activating protein

$1.54+1.66$

Ras GTPase-activating protein-binding protein 1

reticulocalbin-1 precursor

(identified in two spots as fragment)

reticulocalbin-1 precursor

stomatin-like protein 2

stress-70 protein, mitochondrial

observed pl 5.9; theoretical pl 5.9)

(observed pl 5.4; theoretical pl 5.9)

synaptic vesicle membrane protein VAT-1 homolog

RhoA precursor

TRAP1

triosephosphate isomerase

(pl observed 6.2; theoretical pl 6.5)

triosephosphate isomerase

The cell treatment occurred with either $8 \mu \mathrm{g} / \mathrm{mL}$ lovastatin lactone or hydroxy acid for 48 hours. The factor change is presented below with values above 1 representing an increase and values below 1 representing a decrease in protein expression as compared with controls. In some cases (annexin 1 , chloride intracellular channel protein 1, stress-70 protein, triose phosphate isomerase) more then one spot was assigned to one protein. This happens when proteins undergo a post-translational modification as indicated by a shift in the spot's isoelectric point (pl). In these cases, an observed and a theoretical pl values were provided.
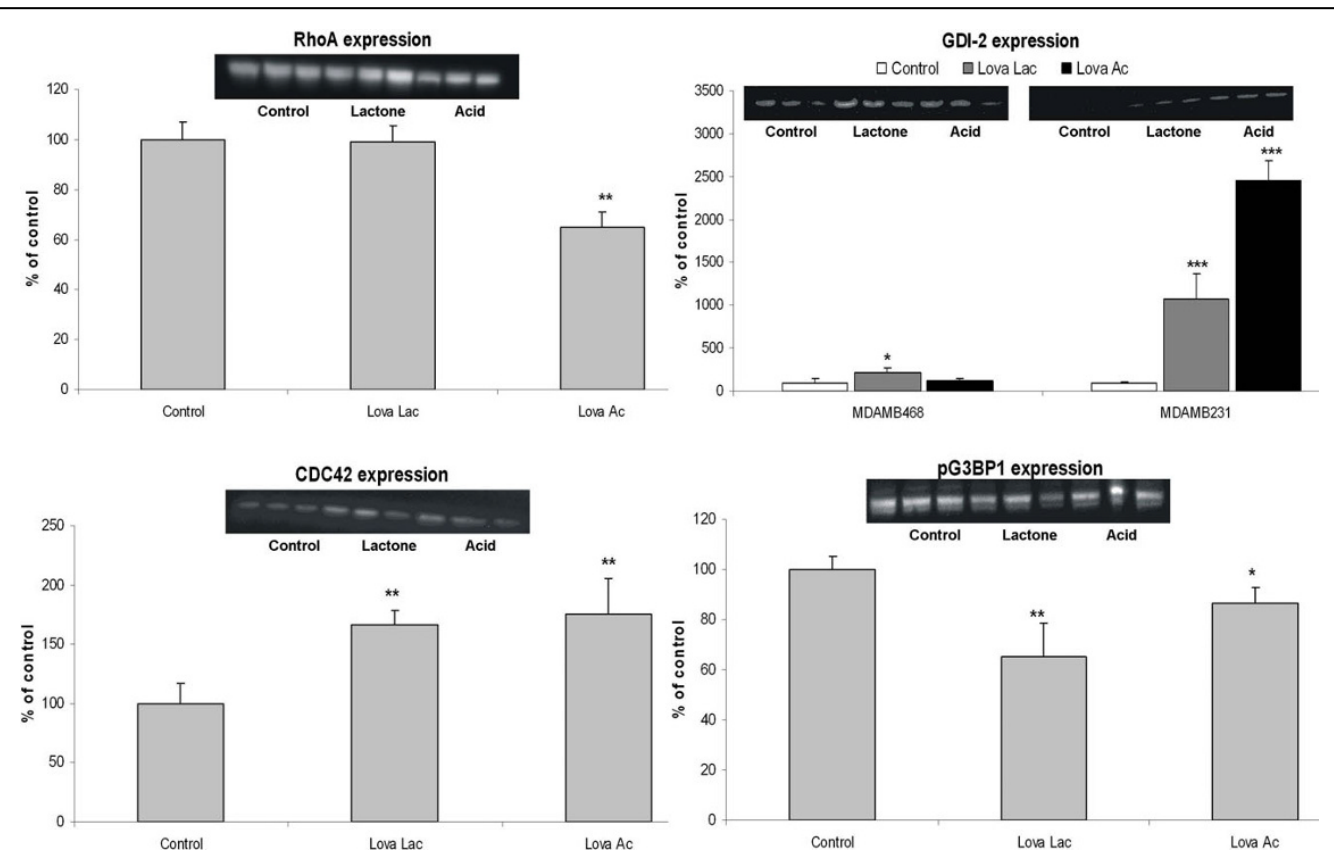

Figure 3 Western blot analysis of proteins involved in small GTPase-mediated cell signaling. Breast cancer cell lines MDAMB231 and MDAMB468 were treated with $8 \mu \mathrm{g} / \mathrm{mL}$ lovastatin lactone (Lova Lac) or lovastatin acid (Lova Ac) for 48 hours. For key proteins, western blot analysis was performed based on MDAMB231 cell extracts (for Ras homolog gene family member A (RhoA), cell division cycle 42 (CDC42) and GTPase-activating protein SH3-domain-binding protein 1 - phospho form (pG3BP1)), otherwise both cell lines are shown. Densitometry data were normalized based on the amount of $\beta$-actin. Data are presented as means \pm standard deviations $(n=3) *{ }^{*} P<0.05$; $\left.{ }^{* *} P<0.05 ;{ }^{* * *} P<0.001\right)$. Gel images were cropped to improve the clarity and conciseness of the presentation. GDI-2, Rho GDP dissociation inhibitor 2. 


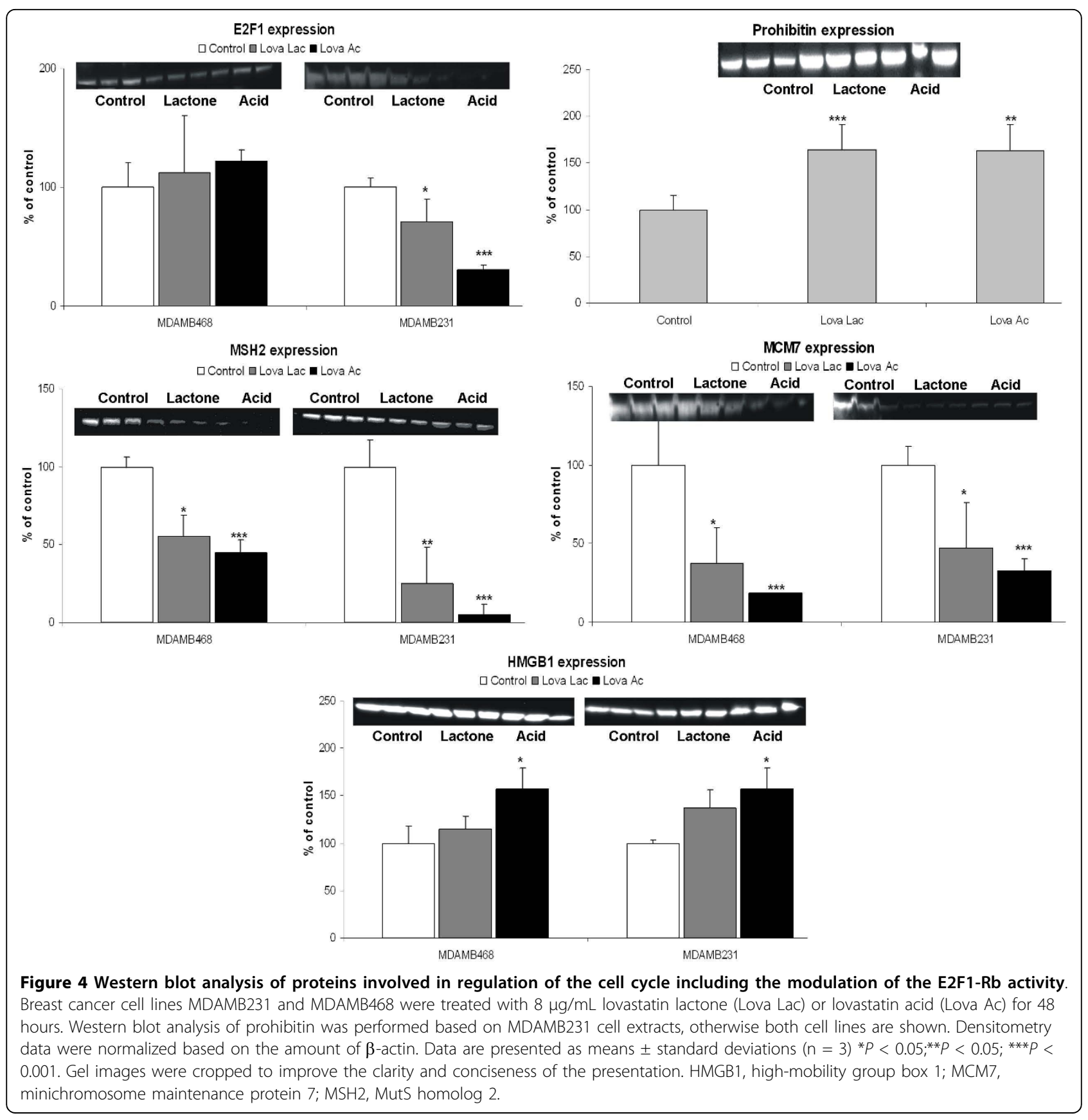

\section{Cell death}

In both cell lines, lovastatin treatment was accompanied by the loss of cell viability. Functional clustering facilitated the identification and subsequent inclusion of a large group of proteins related to the apoptosis signaling. These included: TNF type 1 receptor-associated protein (TRAP-1), $70 \mathrm{kDa}$ subunit of Ku antigen (Ku70), disulfide isomerase ER-60, DJ-1 (PARK-7; Figure 5), cofilin $1 / 2$, heat shock $27 \mathrm{kDa}$, HMGB1, glutathione $\mathrm{S}$ transferase $\mathrm{Pi}$, annexins $\mathrm{A} 1$ and $\mathrm{A} 4$, and nucleophosmin (Table 1).

\section{Cellular metabolism}

Lovastatin treatment altered the expression of proteins involved in the regulation of metabolic processes such as pentose-phosphate pathway (NADP metabolic process): 3-hydroxyisobutyrate dehydrogenase, 6-phosphogluconolactonase, triosephosphate isomerase 1; glycolysis: triosephosphate isomerase 1, alpha enolase, dihydrolipoamide S-acetyltransferase; and tricarboxylic acid cycle activity as indicated by decreased expression of succinate dehydrogenase (ubiquinone) flavoprotein subunit (SDHA) and dihydrolipoamide S-acetyltransferase. ATP citrate lyase, 


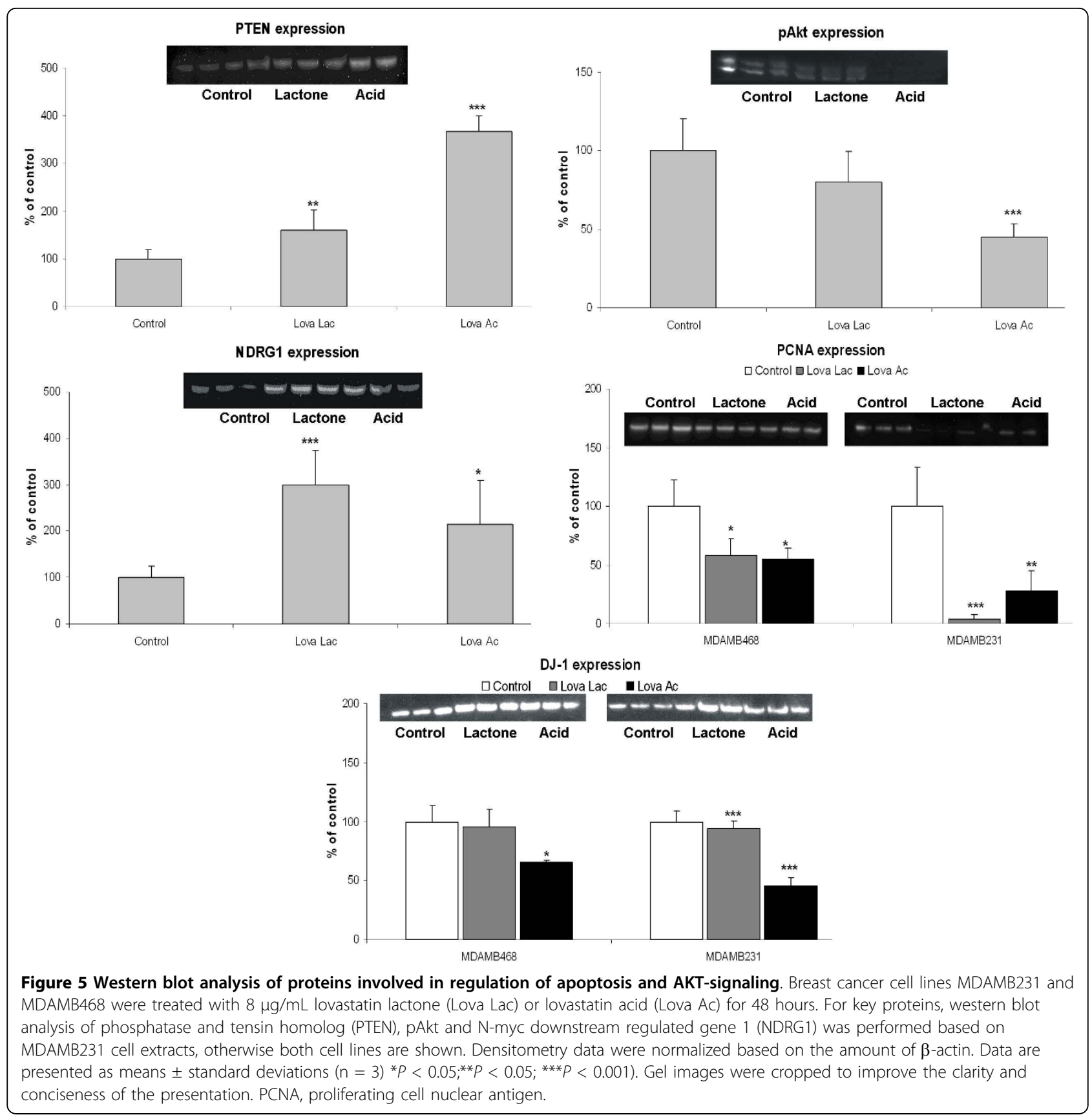

an enzyme involved in synthesis of acetyl-CoA, was downregulated as well (Table 1 and Figure 2b).

\section{Lovastatin induced oxidative stress}

The expression of ROS scavengers peroxiredoxin 2 and peroxiredoxin 3 was upregulated, while the expression of a protein related to the family of thioredoxins, the thioredoxin domain-containing protein 12, was downregulated (Table 1). An increase in expression levels of two isoforms of glutathione S-transferase, GST-Pi and GST omega-1, was observed (Table 1). Both of these isoforms are active in the detoxification of ROS-induced damage (Figure 2b).

\section{Correlation of proteomic data with western blot protein expression analysis}

In order to confirm the two-dimensional gel electrophoresis proteomics mass spectrometry data, western blot analysis was performed on selected proteins, the results of which are presented in Figures 3 to 5 . When not performed on both cell lines, the analysis was performed only on the more sensitive of the two, the 
Table 2 Intracellular concentrations ( $\mathrm{nmol} / \mathrm{g}$ cell weight) of ${ }^{13} \mathrm{C}$-labeled endogenous metabolites (glycolysis and TCA cycle intermediates, glucose) and lipid metabolites (choline-containing phospholipids, cholesterol)

\begin{tabular}{|c|c|c|c|}
\hline & Control & Lovastatin lactone & $\begin{array}{l}\text { Lovastatin } \\
\text { acid }\end{array}$ \\
\hline${ }^{13} \mathrm{C}$-lactate & $612 \pm 36$ & $252 \pm 51^{* *}$ & $343 \pm 15^{* *}$ \\
\hline glycolysis int & $845 \pm 21$ & $369 \pm 13^{* * *}$ & $467 \pm 52^{* * *}$ \\
\hline TCA cycle int & $913 \pm 232$ & $189 \pm 28^{* *}$ & $213 \pm 56^{* *}$ \\
\hline glucose $_{\text {intracell }}$ & $1918 \pm 382$ & $2691 \pm 283^{*}$ & $2758 \pm 231^{*}$ \\
\hline citrate & $323 \pm 46$ & $98 \pm 33^{* * *}$ & $153 \pm 35^{* *}$ \\
\hline glutathione & $2595 \pm 168$ & $871 \pm 72^{* * *}$ & $1149 \pm 78^{* *}$ \\
\hline choline-PL & $3757 \pm 534$ & $2158 \pm 275^{* *}$ & $2672 \pm 542^{*}$ \\
\hline chol C18+C19 & $3914 \pm 582$ & $2125 \pm 289^{* *}$ & $2467 \pm 351^{* *}$ \\
\hline
\end{tabular}

The values were calculated based on MDAMB468 cell extracts as assessed by ${ }^{1} \mathrm{H}$-NMR and ${ }^{13} \mathrm{C}$-NMR. The cells were incubated with $8 \mu \mathrm{g} / \mathrm{mL}$ lovastatin lactone or hydroxy acid for $\mathbf{4 8}$ hours. Values are presented as means \pm standard deviation of three independent experiments. Significance levels: ${ }^{*} P$ $<0.05$; ** $P<0.005$; *** $P<0.001$ were determined by analysis of variance (with post-hoc pairwise multiple comparison Tukey-test). chol, cholesterol; choline-PL, choline-containing phospholipids; glu, glutamate; glycolysis int, glycolysis intermediates: ${ }^{13} \mathrm{C}$-lactate $+{ }^{13} \mathrm{C}$-alanine, TCA int: TCA cycle intermediates: $(\mathrm{C} 2+\mathrm{C} 3+\mathrm{C} 4)$-glutamate $+(\mathrm{C} 2+\mathrm{C} 3)$-glutamine.

MDAMB231. The results obtained from the western blot analysis corresponded well with the results from the proteomics database search. The expression of the small GTPases, GDI-2 and CDC42, showed an increase in MDAMB231 cells. Analysis of the expression of the membrane-bound, active RhoA surprisingly indicated no change after exposure to lovastatin lactone, in contrast to a significant decrease during treatment with lovastatin acid. In the protein group associated with the E2F1 pathway, the expression of E2F1, as well as MSH2, MCM7 and HMGB1 was more pronounced in the lovastatin acid group than in the lovastatin lactone treatment group. Time-dependent changes were, again, more prominent in MDAMB231 than in MDAMB468 cells. The same specific trend towards higher sensitivity of MDAMB231 cells to lovastatin acid continued in the expression of proteins related to Akt signaling. Although the expression of PTEN increased, its associated regulator protein DJ-1 was down-regulated, as was pAkt itself. Conversely, NDRG1, an Akt downstream target, was upregulated by lovastatin lactone and acid.

\section{Metabonomic analysis}

Energy producing pathways: glycolysis and Krebs cycle As revealed by ${ }^{1} \mathrm{H}-\mathrm{NMR}, 48$ hour incubation of MDAMB468 cells with $8 \mu \mathrm{g} / \mathrm{mL}$ lovastatin lactone or lovastatin acid strongly inhibited glycolytic activity by decreasing the de novo production of ${ }^{13} \mathrm{C}$-alanine and ${ }^{13} \mathrm{C}$-lactate. The ${ }^{13} \mathrm{C}$-lactate concentrations (mean \pm standard deviation) decreased to $41 \pm 8 \%$ of control $(P<$ $0.001, \mathrm{n}=3)$ during lovastatin lactone exposure and $56 \pm$ $3 \%$ of control $(P<0.005, \mathrm{n}=3)$ during lovastatin acid exposure (Table 2 and Figure 6). Lovastatin lactone and acid also induced a strong reduction in the Krebs cycle activity, as measured through the ${ }^{13} \mathrm{C}$-enrichment of Krebs cycle products, such as glutamine and glutamate. Concentration of C4-glutamate decreased from $474 \pm 72$ $\mathrm{nmol} / \mathrm{g}$ in controls to $91 \pm 11 \mathrm{nmol} / \mathrm{g}$ in lovastatin lactone $(P<0.001, \mathrm{n}=3)$ and to $111 \pm 17 \mathrm{nmol} / \mathrm{g}(P<$ $0.001, \mathrm{n}=3$ ) in lovastatin acid-treated cells (Table 2 and Figure 6). Furthermore, lovastatin acid reduced the concentration of citrate, a direct Krebs cycle intermediate to $30 \pm 11 \%$ of control $(P<0.005, \mathrm{n}=3$, Table 2 and Figure $6)$. The reduction in the activity of these two major glucose metabolizing processes was accompanied by an accumulation of intracellular glucose (Table 2 and Figure 6). In regards to surrogate markers for ROS formation, ${ }^{1} \mathrm{H}-\mathrm{NMR}$ analysis of cell extracts revealed a highly significant decline in total cellular glutathione concentrations (from $2595 \pm 168 \mathrm{nmol} / \mathrm{g}$ in controls to $871 \pm 72$ and $1149 \pm 78 \mathrm{nmol} / \mathrm{g}$ in lovastatin lactone and acid treated cells; $P<0.001, \mathrm{n}=3$, Table 2 and Figure 6), suggesting an increase in oxidative damage.

\section{Lipid metabolism}

Both lovastatin forms led to similar changes in the lipid constitution of the cell, causing a reduction in the signals for cholesterol, choline-containing phospholipids and fatty acids (Figure 7). However, the changes were more pronounced in lovastatin lactone-treated cells where the concentration of total choline-containing phospholipids decreased to $57 \pm 7 \%(P<0.005, \mathrm{n}=3)$, cholesterol C18 to $55 \pm 6 \%(P<0.005, \mathrm{n}=3)$, cholesterol $\mathrm{C} 19$ to $54 \pm 9 \%(P<0.05, \mathrm{n}=3)$, and concentrations of different unsaturated fatty acids declined to 50 to $65 \%$ of control values (Table 2 and Figure 7).

\section{Discussion}

Although the beneficial effects of HMG-CoA reductase inhibitors in lowering cholesterol are well established, their importance in the area of cancer therapeutics is only now beginning to gain greater recognition $[1,2,10,12]$. Normal cells respond to statin inhibition of HMG-CoA reductase activity through a feedback upregulation of sterol- and lipid-synthesizing gene programs, including the low-density lipid receptor [30]. Cancer cells usually exhibit elevated levels of HMG-CoA reductase and low-density lipid receptor. Thus, cancer cells are potentially more sensitive than normal cells to the isoprenoid-depleting effects of statins [31]. In this study, we used a combination of 2DE-proteomic and NMRbased metabonomic strategies to further investigate the molecular mechanisms by which lovastatin exhibits its reported antitumor activity.

Two estrogen receptor-negative breast cancer cell lines, MDAMB231 and MDAMB468, were treated for 48 hours with $8 \mu \mathrm{g} / \mathrm{mL}$ lovastatin lactone or lovastatin 

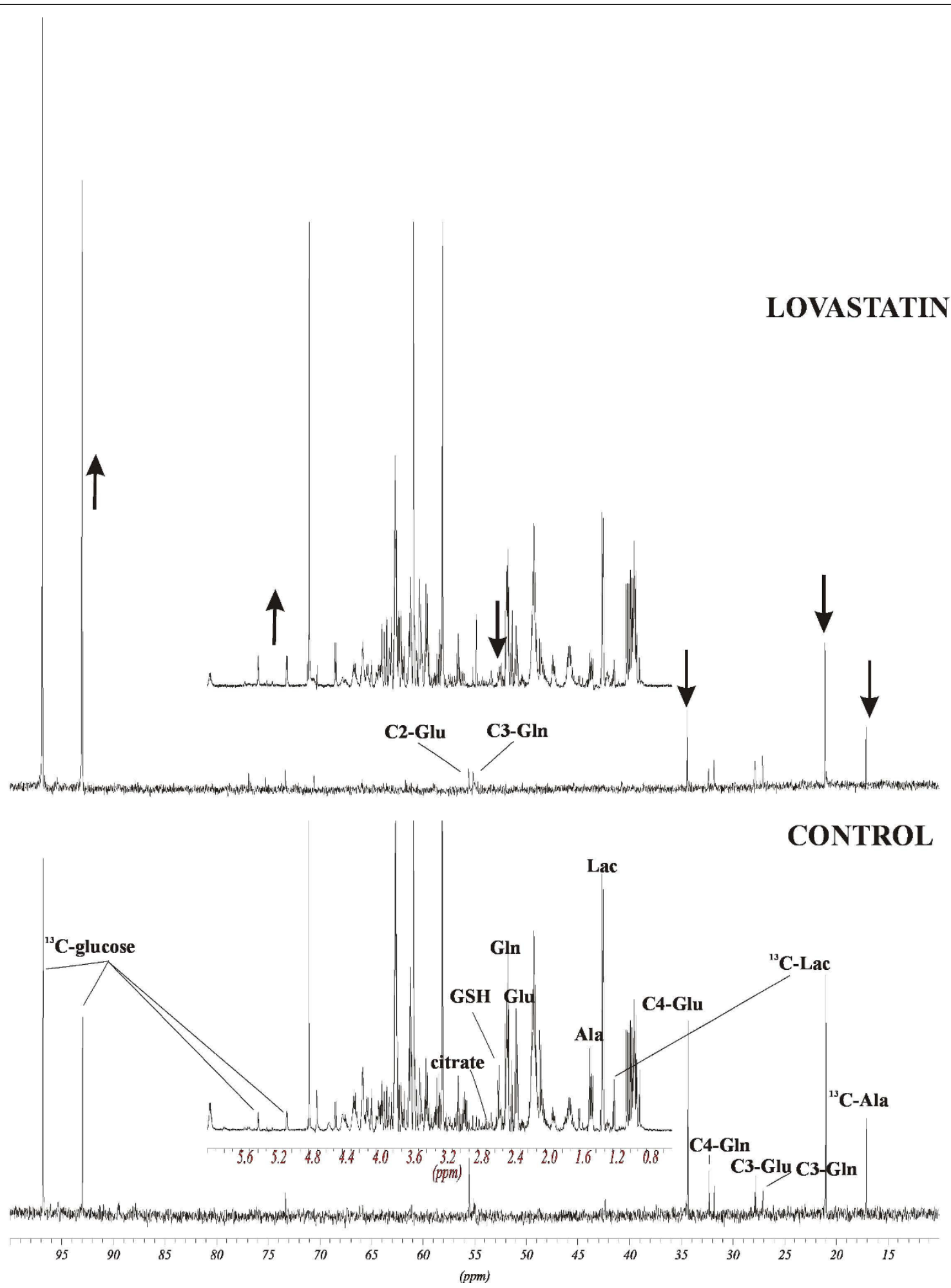

Figure 6 Changes in intracellular ${ }^{13} \mathrm{C}$-labeled -alanine, -lactate, -glucose and -glutamine signals in MDAMB468 cells treated with $8 \mu \mathrm{g} /$ $\mathrm{mL}$ lovastatin acid for $\mathbf{4 8}$ hours. ${ }^{13} \mathrm{C}-\mathrm{NMR}$ spectra with embedded, corresponding ${ }^{1} \mathrm{H}-\mathrm{NMR}$ spectra are shown (including citrate at $2.52+2.69$ ppm). Arrows indicate the direction of signal changes (increase or decrease). Ala, alanine; Gln, glutamine; Glu, glutamine; GSH, total glutathione; Lac, lactate. 


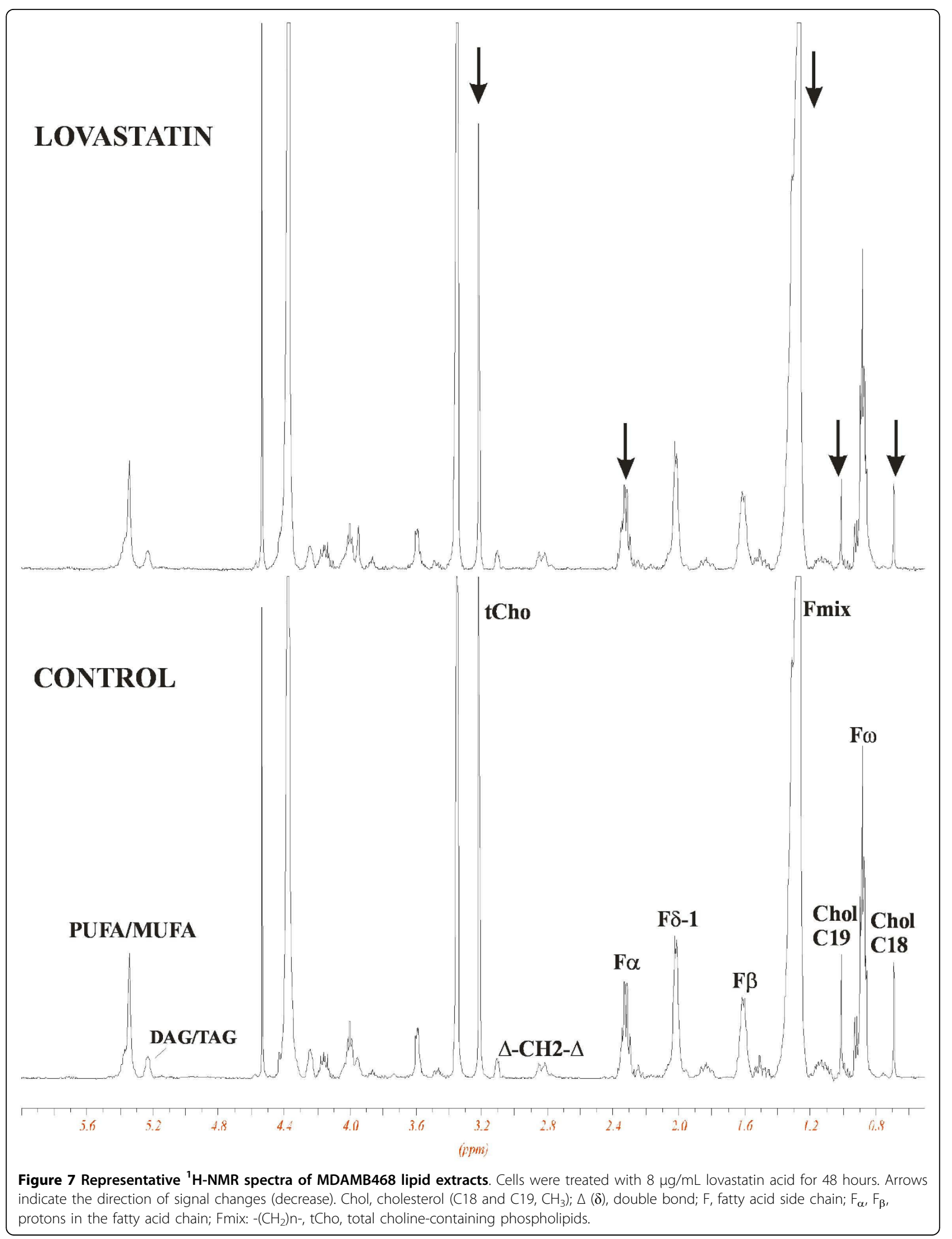


hydroxy acid. Although MDAMB231 cells express PTEN and $\mathrm{Rb}, \mathrm{MDAMB} 468$ does not express either of these. In regards to their sensitivity to lovastatin, both cell lines exhibited similar $\mathrm{IC}_{50}$ values. However, in regard to changes detected by 2DE, MDAMB231 cells demonstrated alterations in a larger number of proteins and presumably a greater sensitivity to lovastatin. After exposure to lovastatin acid or lactone, the majority of proteins detected did not show differences in changes between the two treatment groups. This may partly be supported by previous data, which shows that in a cell culture medium, $80 \%$ of the lactone prodrug converts to the acid form within 9 hours and achieves complete conversion within 24 hours [32]. Western blot analysis further confirmed that the observed lovastatin-induced changes in protein expression were more pronounced in the MDAMB231 than the MDAMB468 cells. This suggests that their phenotypic differences (e.g. PTEN, Rb expression) may be responsible for the stronger response to lovastatin. In MDAMB231 cells, the differences between the lovastatin lactone and lovastatin acid were more distinct, in general with lovastatin acid exhibiting greater effects, especially on the GTPase, E2F and AKT signaling pathways (Figures 3, 4, 5 and Figure 8).

Inhibition of the mevalonate pathway by lovastatin suppresses the synthesis of two substrates that provide the isoprenoid moieties for post-translational modifications of diverse proteins: farnesyl and geranylgeranyl diphosphates [33]. This suppresses the essential posttranslational processing of proteins regulating cell proliferation and viability [34]. Examples are the Ras and Rho proteins, which require attachment of FPP or GGPP groups prior to their activation and delocalization to the plasma membrane [35]. Several groups have reported that the addition of mevalonate pathway intermediates such as mevalonate, GGPP and partially FPP, can diminish the pro-apoptotic effects of statins [36]. Also, the addition of mevalonate (at 100-fold the lovastatin concentration) has been shown to release the cells from the

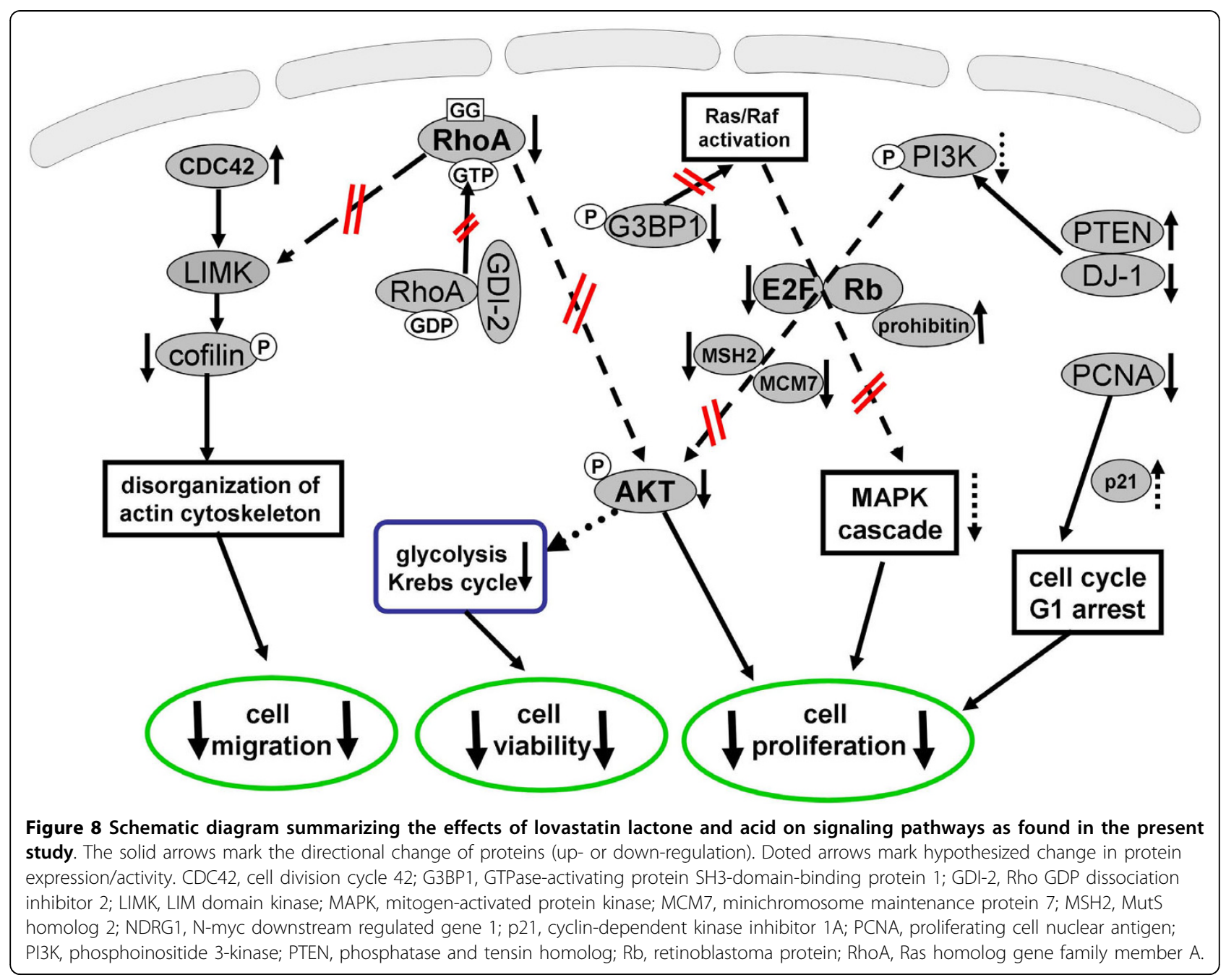


G1 cell cycle arrest induced by lovastatin and allow for entry into late G1, S and G2/M phases [37]. This points to the predominant role of protein geranylgeranylation in statin-induced apoptosis in cancer cells [10,38,39]. In our study, the addition of mevalonate and GGPP reversed the effects of lovastatin on the inhibition of breast cancer cell proliferation, whereas FPP could only partially rescue cells from the antiproliferative effect of lovastatin. Although FPP lies upstream of GGPP in the mevalonate pathway, the addition of FPP would not be capable of restoring protein geranylgeranylation because a second molecule, isopentenyl pyrophosphate ( $\mathrm{PPi})$, is required for the conversion of FPP to GGPP. Isopentenyl PPi is also depleted by statin exposure, and is therefore unavailable to the statin-treated cells.

Small GTPase-proteins are frequently discussed targets of statins $[27,28]$. Our proteomics data identified RhoA, a protein implicated in the control of cell growth, apoptosis [40] and tumorigenesis [41]. We demonstrated that the translocalization of RhoA in MDAMB231 cells to the membrane was suppressed by lovastatin (Figures 3 and 8). We also observed an increased expression of GDI-2, which stabilizes the non-activated form of RhoA and prevents its relocalization to the membrane and subsequent activation by GGPP (Figure 8). In addition, lovastatin acid treatment changed the expression of Ras-GTPase activating binding protein G3BP1 (down-regulation of its unmodified and its active phospho form) and CDC42 (upregulated; Figures 3 and 8). The latter acts as a signal transduction convergence point in intracellular signaling networks mediating multiple signaling pathways, including tyrosine kinase receptors, heterodimeric G-protein coupled receptors and cytokine receptors [42]. G3BP1 directly associates with the $\mathrm{SH} 3$ domain of GTPase-activating protein, functioning as an effector of Ras [43]. Moreover, we identified a decrease of cofilin $1 / 2$, a CDC42 and LIM kinase target protein [44] (Figure 8). Posttranslational modification analysis (using the ProteinPilot and special factors: phosphorylation emphasis, paragon search method) revealed that the cofilin form decreased by lovastatin was phosphorylated at S3, S8 and T16. This reduction of the phosphorylated cofilin is in accordance with previous reports [45].

Regulation of the cell cycle including the modulation of Rb-E2F1 activity is the second major signaling pathway affected by lovastatin treatment in breast cancer cells (Figure 8). PCNA, a cell proliferation marker and a control point for DNA repair [46], was found to be significantly down-regulated by lovastatin in both cell lines. Its downregulation has been proven to correlate with the overexpression of p 21 and is followed by a G1 arrest in cells [47]. The latter has been shown to occur in cells treated with statins $[12,37,48,49]$, making them popular as agents for reversible synchronization of cells in the G1 phase of the cell cycle [37].

The upregulation of the cell-cycle regulatory protein prohibitin, a tumor suppressor protein able to co-localize with $\mathrm{Rb}$ and suppress the E2F1 and p53 transcriptional activity [50], is another novel finding of our study. Despite the observation that prohibitin is upregulated in both cell lines following lovastatin treatment (to a higher degree in MDAMB231 cells), an expected downregulation of E2F1 only occurred in $\mathrm{Rb}$-positive MDAMB231 cells. Therefore, while acting synergistically with $\mathrm{Rb}$ in the suppression of E2F1, prohibitin does not seem to impair E2F1 expression alone. As for the downstream targets in the E2F-mediated pathway, we identified changes in both MCM7 [51] and MSH2 [52]. Although MCM7 belongs to the cell cycle DNA checkpoints, MSH2 is a representative member of MMR systems. The expression of both of these was significantly suppressed by lovastatin. Interestingly, the suppression occurred in both cell lines, suggesting that it may not be mediated exclusively through E2F1 reduction, and that perhaps other regulatory pathways are also affected by lovastatin.

Statin-treated breast cancer cells die through apoptosis $[12,48,49]$. It was therefore not surprising that a large number of identified proteins was associated with the programmed cell death pathway. In addition to prohibitin, RhoB and cofilin $1 / 2$, there was also suppression of TRAP-1 and Ku70 expression. Both of these proteins protect the cells from apoptosis and oxidative stress $[53,54]$. These data comply with previous reports suggesting that increased oxidative stress may be a cause of statin-induced cytotoxicity in breast cancer $[13,49]$. Recently, it has been shown that fluvastatin and simvastatin enhance NO levels and increase iNOS RNA and protein expression in breast cancer MCF-7 cells, indicating that iNOS-mediated NO is responsible, in part, for the proapoptotic, tumoricidal, and antiproliferative effect of statins [14]. Furthermore, the cell death of MCF-7 cells incubated with $\mathrm{N}$-acetyl-L-cysteine plus statins could almost be reversed [49], supporting our results that oxidative stress plays an important role in the cell death induced by statins.

In terms of metabolic changes, the downregulation of glycolytical enzymes triosephosphate isomerase, alphaenolase and dihydrolipoamide acetyltransferase and tricarboxylic acid cycle enzymes such as SDHA represent potential pathways by which lovastatin may induce cell death through the suppression of energy-producing pathways. Glycolysis is the primary energy-producing pathway in cancer cells and is therefore a highly valuable target in anti-cancer therapy [55]. The changes in enzyme expressions correlate with the NMR-based metabolic profiles: decreased production of de novo 
${ }^{13} \mathrm{C}$-lactate, ${ }^{13} \mathrm{C}$-alanine and C4-glutamate and accumulation of intracellular glucose (Figures 6 and 8).

Due to its close relation to anaerobic glycolysis [56], we chose to investigate the role of the protein kinase Akt. A downregulation of the active p-Akt form was detected in both cell lines. One possible mechanism of Akt deactivation involves its regulation by PTEN, inhibiting the ability of phosphatidylinositol 3-kinase to phosphorylate Akt [57]. As expected, we observed an induction of PTEN expression by lovastatin in the PTEN-expressing MDAMB231 cell line (Figures 5 and $8)$. The induction was more pronounced when the cells were treated with the lovastatin acid than with its lactone form. PTEN itself is known for tumor suppression and frequently mutates in a wide variety of cancers and is functionally involved in their metastatic advancement [58]. The ability of statins to stimulate the overexpression of PTEN and their importance for therapeutic and preventative uses in cancer, diabetes mellitus and cardiovascular disease has been recognized in the past [59-61]. To date, several mechanisms have been discussed including the transcriptional activation of peroxisome proliferator-activated receptor and upregulation of the sterol response element-binding protein [59-61]. In our proteomics data we have identified a protein affected by lovastatin described in the literature as a negative regulator of PTEN $[62,63]$. This protein, known as DJ-1/PARK7, is an oncogene that cooperates with $\mathrm{H}$ Ras and transforms cells by increasing cell proliferation and resistance to cell cycle arrest [64]. In breast cancer, overexpression of DJ-1 positively correlates with phosphorylated Akt and poor disease prognosis [62]. In both of our breast cancer cell lines (PTEN expressing MDAMB231 and PTEN lacking MDAMB468), lovastatin acid successfully decreased the expression of DJ-1 (Figures 5 and 8). Conversely, lovastatin lactone, previously shown to induce PTEN in a less effective manner than the acid form, failed to decrease DJ-1 expression. This result confirms that the expression of DJ-1 is correlated with the expression of PTEN and suggests that DJ-1 is able to regulate the activity of the Akt kinase even in the absence of PTEN. DJ-1 and PTEN synergistically lowered the expression of the active pAkt form, but only when cells were treated with lovastatin acid. Our results suggest that DJ-1, and not PTEN, might be the key regulator of pAkt expression in lovastatin-treated breast cancer cells. This hypothesis will require further evaluation. The influence of lovastatin is also detected downstream of the DJ-1/PTEN-regulated Akt pathway on the expression of yet another clinically important protein, NDRG1. NDRG1 not only plays an important role in metastatic tumor progression, it has also been observed to slow the advancement of breast cancer in a clinical study and, interestingly, to be regulated by
PTEN through an Akt-dependant pathway [65]. The downregulation of NDRG1 occurred in cells treated with either lovastatin lactone or lovastatin acid, indicating that its expression might be regulated through pathways other than the inhibition of pAkt.

\section{Correlation between metabonomic and proteomic data}

Dihydrolipoamide S-acetyltransferase and ATP citrate lyase are enzymes that are involved in the production of acetyl-CoA. A reduction in their expression decreases production of acetyl-CoA. This has a negative effect on fatty acid and cholesterol synthesis. Our NMR data revealed a significant reduction of choline-containing phospholipids, fatty acids and cholesterol concentrations as a result of lovastatin treatment. Additionally, we identified a transporter, the sterol carrier protein-X/2, which is not only involved in cholesterol, fatty acids and phospholipids trafficking [66], but also has a high affinity for isoprenyl pyrophosphates (GGPP, FPP, GPP) [67]. Its downregulation suggests that both, the production of isoprenylated intermediates and their transport are influenced by lovastatin.

\section{Conclusions}

Overall, our data indicated that in the studied breast cancer cells lovastatin lactone and acid affect small GTPase, E2F and AKT signaling pathway (Figure 8). Lovastatin-treated breast cancer cells showed changes in the activity of various small GTPases, primarily through the inhibition of the isoprenylation of RhoA. This inhibition is partially mediated by the stabilization of the non-active RhoA form, which is achieved through an increase in expression of Rho inhibitor GDI-2. Lovastatin decreased the activity of G3BP1, a GTPase that is over-expressed in a number of human malignancies. It can be speculated that this may constitute a novel target for the sensitization of cancer cells to genotoxic stress. Lovastatin also modulated the E2F1 pathway by regulating the expression of prohibitin and $\mathrm{Rb}$ and resulted in changes of the E2F-downstream targets MCM7 and MSH2. The deactivation of the AKT-pathway through an upregulation of PTEN and down-regulation of DJ-1 represents an additional target by which lovastatin possibly regulates tumor cell survival and progression. It is important to mention the induction of oxidative stress, suppression of glycolytic and Krebs cycle activity as well as lipid biosynthesis as metabolic consequences to lovastatin exposure.

\section{Abbreviations}

ANOVA: analysis of variance; CDC42: cell division cycle 42; DAVID: Database for Annotation, Visualization, and Integrated Discovery; DTT: dithiothreitol; ER: estrogen receptor; FPP: farnesyl pyrophosphate; G3BP1: phospho-GTPase activating protein binding protein 1; GDI-2: GDP dissociation inhibitor 2; 
GGPP: geranylgeranyl diphosphate; HMG-CoA: 3-hydroxy-3-methylglutaryl coenzyme reductase; HMGB1: high-mobility group protein B1; iNOS: nitric oxide synthase; Ku70: 70 kDa subunit of Ku antigen; LC: liquid chromatography; MCM7: minichromosome maintenance protein 7; MMR: DNA-mismatch repair; MS: mass spectrometry; MSH2: MutS homolog 2; NDRG1: N-myc downstream regulated gene 1; NMR: nuclear magnetic resonance; NO: nitric oxide; PCA: perchloric acid; PCNA: proliferating cell nuclear antigen; PTEN: phosphatase and tensin homolog; Rb: retinoblastoma; RhoA: Ras homolog gene family member A; ROS: reactive oxygen species; SDHA: succinate dehydrogenase (ubiquinone) flavoprotein subunit; TRAP: TNF type 1 receptor-associated protein; TSP: (Trimethylsilyl) propionic-2,2,3,3acid

\section{Acknowledgements}

The authors would like to thank Eurofins Medinet Inc., Denver for providing technical and instrumental support. This work was supported by the United States National Institutes of Health, grants R01 HL071805 and P30 DK048520 (Mass Spectrometry Core).

\section{Author details}

${ }^{1}$ Department of Anesthesiology, Clinical Research and Development, University of Colorado Denver, 12401 East 17th Avenue, Aurora, CO, 80045, USA. Eurofins Medinet Inc., 1999 North Fitzsimons Parkway, Aurora, CO, 80045, USA.

\section{Authors' contributions}

JeK carried out the proteomic and metabonomic studies and drafted the manuscript; TS helped with the NMR analyses and cell culture work; VM carried out the cell culture work; UC participated in the study design, coordination, data interpretation and helped to draft the manuscript; JoK helped with proteomics data analysis and statistics, participated in the study design and coordination and helped to draft the manuscript. All authors read and approved the final manuscript.

\section{Competing interests}

The authors declare that they have no competing interests.

Received: 3 September 2009 Revised: 29 January 2010

Accepted: 5 March 2010 Published: 5 March 2010

\section{References}

1. Kumar AS, Benz CC, Shim V, Minami CA, Moore DH, Esserman LJ: Estrogen receptor-negative breast cancer is less likely to arise among lipophilic statin users. Cancer Epidemiol Biomarkers Prev 2008, 17:1028-1033.

2. Kwan ML, Habel LA, Flick ED, Quesenberry CP, Caan B: Post-diagnosis statin use and breast cancer recurrence in a prospective cohort study of early stage breast cancer survivors. Breast Cancer Res Treat 2008, 109:573-579.

3. Cauley JA, Zmuda JM, Lui LY, Hillier TA, Ness RB, Stone KL, Cummings SR, Bauer DC: Lipid-lowering drug use and breast cancer in older women: a prospective study. J Womens Health (Larchmt) 2003, 12:749-756.

4. Boudreau DM, Gardner JS, Malone KE, Heckbert SR, Blough DK, Daling JR: The association between 3-hydroxy-3-methylglutaryl conenzyme A inhibitor use and breast carcinoma risk among postmenopausal women: a case-control study. Cancer 2004, 100:2308-2316.

5. Larner J, Jane J, Laws E, Packer R, Myers C, Shaffrey M: A phase I-II trial of lovastatin for anaplastic astrocytoma and glioblastoma multiforme. Am J Clin Oncol 1998, 21:579-583.

6. Katz MS, Minsky BD, Saltz LB, Riedel E, Chessin DB, Guillem JG: Association of statin use with a pathologic complete response to neoadjuvant chemoradiation for rectal cancer. Int J Radiat Oncol Biol Phys 2005, 62:1363-1370.

7. Sassano A, Platanias LC: Statins in tumor suppression. Cancer Lett 2008, 260:11-19.

8. Goldstein $J$, Brown MS: Regulation of the mevalonate pathway. Nature 1990, 343:425-430

9. Etienne-Manneville S, Hall A: Rho GTPases in cell biology. Nature 2002, 420:629-635.

10. Cafforio P, Dammacco F, Gernone A, Silvestris F: Statins activate the mitochondrial pathway of apoptosis in human lymphoblasts and myeloma cells. Carcinogenesis 2005, 26:883-891.
11. Graaf MR, Richel DJ, van Noorden CJ, Guchelaar HJ: Effects of statins and farnesyltransferase inhibitors on the development and progression of cancer. Cancer Treat Rev 2004, 30:609-641.

12. Campbell MJ, Esserman LJ, Zhou Y, Shoemaker M, Lobo M, Borman E, Baehner F, Kumar AS, Adduci K, Marx C, Petricoin EF, Liotta LA, Winters M, Benz S, Benz CC: Breast cancer growth prevention by statins. Cancer Res 2006, 66:8707-8714.

13. Kuhajda FP, Jenner K, Wood FD, Hennigar RA, Jacobs LB, Dick JD, Pasternack GR: Fatty acid synthesis: a potential selective target for antineoplastic therapy. Proc Natl Acad Sci USA 1994, 91:6379-6383.

14. Kotamraju S, Williams CL, Kalyanaraman B: Statin-induced breast cancer cell death: role of inducible nitric oxide and arginase-dependent pathways. Cancer Res 2007, 67:7386-7394.

15. Takeda I, Maruya S, Shirasaki T, Mizukami H, Takahata T, Myers JN, Kakehata S, Yagihashi S, Shinkawa H: Simvastatin inactivates beta1integrin and extracellular signal-related kinase signaling and inhibits cell proliferation in head and neck squamous cell carcinoma cells. Cancer Sci 2007, 98:890-899.

16. Hirai A, Nakamura S, Noguchi Y, Yasuda T, Kitagawa M, Tatsuno I, Oeda T, Tahara K, Terano T, Narumiya S, Kohn LD, Saito Y: Geranylgeranylated rho small GTPase(s) are essential for the degradation of p27Kip1 and facilitate the progression from $\mathrm{G} 1$ to $S$ phase in growth-stimulated rat FRTL-5 cells. J Biol Chem 1997, 272:13-16.

17. Seillier-Moiseiwitsch F: The Proteomics Protocols Handbook. 2005, 239-258.

18. Biosciences A: Melanie: The 2D gel analysis software User Manual. Amersham Biosciences and Geneva Bioinformatics SA 2004

19. Laudi S, Steudel W, Jonscher K, Schoning W, Schniedewind B, Kaisers U, Christians U, Trump S: Comparison of lung proteome profiles in two rodent models of pulmonary arterial hypertension. Proteomics 2007 7:2469-2478

20. Havlis J, Thomas H, Sebela M, Shevchenko A: Fast-response proteomics by accelerated in-gel digestion of proteins. Anal Chem 2003, 75:1300-1306.

21. Serkova N, Brand A, Christians U, Leibfritz D: Evaluation of the effects of immunosuppressants on neuronal and glial cells in vitro by multinuclear magnetic resonance spectroscopy. Biochim Biophys Acta 1996, 1314:93-104

22. Klawitter J, Kominsky DJ, Brown JL, Klawitter J, Christians U, Leibfritz D, Melo JV, Eckhardt SG, Serkova NJ: Metabolic characteristics of imatinib resistance in chronic myeloid leukaemia cells. Br J Pharmacol 2009, 158:588-600.

23. Kominsky DJ, Klawitter J, Brown JL, Boros LG, Melo JV, Eckhardt SG, Serkova NJ: Abnormalities in glucose uptake and metabolism in imatinibresistant human BCR-ABL-positive cells. Clin Cancer Res 2009, 15:3442-3450.

24. Klawitter J, Anderson N, Klawitter J, Christians U, Leibfritz D, Eckhardt SG, Serkova NJ: Time-dependent effects of imatinib in human leukaemia cells: a kinetic NMR-profiling study. Br J Cancer 2009, 100:923-931.

25. Zwingmann C, Leibfritz D, Hazell AS: Energy metabolism in astrocytes and neurons treated with manganese: relation among cell-specific energy failure, glucose metabolism, and intercellular trafficking using multinuclear NMR-spectroscopic analysis. J Cereb Blood Flow Metab 2003, 23:756-771.

26. Zwingmann $C$, Chatauret N, Leibfritz D, Butterworth RF: Selective increase of brain lactate synthesis in experimental acute liver failure: results of a [H-C] nuclear magnetic resonance study. Hepatology 2003, 37:420-428.

27. Konstantinopoulos PA, Karamouzis MV, Papavassiliou AG: Post-translational modifications and regulation of the RAS superfamily of GTPases as anticancer targets. Nat Rev Drug Discov 2007, 6:541-555.

28. Swanson KM, Hohl RJ: Anti-cancer therapy: targeting the mevalonate pathway. Curr Cancer Drug Targets 2006, 6:15-37.

29. Lei M: The MCM complex: its role in DNA replication and implications for cancer therapy. Curr Cancer Drug Targets 2005, 5:365-380.

30. Istvan ES, Deisenhofer J: Structural mechanism for statin inhibition of HMG-CoA reductase. Science 2001, 292:1160-1164.

31. Liao JK: Isoprenoids as mediators of the biological effects of statins. $J$ Clin Invest 2002, 110:285-288

32. Dimitroulakos J, Ye LY, Benzaquen M, Moore MJ, Kamel-Reid S, Freedman MH, Yeger H, Penn LZ: Differential sensitivity of various pediatric cancers and squamous cell carcinomas to lovastatin-induced apoptosis: therapeutic implications. Clin Cancer Res 2001, 7:158-167. 
33. Hancock JF, Magee Al, Childs JE, Marshall CJ: All ras proteins are polyisoprenylated but only some are palmitoylated. Cell 1989, 57:1167-1177.

34. Mackay DJ, Hall A: Rho GTPases. J Biol Chem 1998, 273:20685-20688.

35. Casey PJ, Thissen JA, Moomaw JF: Enzymatic modification of proteins with a geranylgeranyl isoprenoid. Proc Natl Acad Sci USA 1991, 88:8631-8635.

36. Zhong WB, Wang CY, Chang TC, Lee WS: Lovastatin induces apoptosis of anaplastic thyroid cancer cells via inhibition of protein geranylgeranylation and de novo protein synthesis. Endocrinology 2003, 144:3852-3859.

37. Javanmoghadam-Kamrani S, Keyomarsi K: Synchronization of the cell cycle using lovastatin. Cell Cycle 2008, 7:2434-2440.

38. Wong WW, Clendening JW, Martirosyan A, Boutros PC, Bros C, Khosravi F, Jurisica I, Stewart AK, Bergsagel PL, Penn LZ: Determinants of sensitivity to lovastatin-induced apoptosis in multiple myeloma. Mol Cancer Ther 2007, 6:1886-1897.

39. Xia Z, Tan MM, Wong WW, Dimitroulakos J, Minden MD, Penn LZ: Blocking protein geranylgeranylation is essential for lovastatin-induced apoptosis of human acute myeloid leukemia cells. Leukemia 2001, 15:1398-1407.

40. Coleman ML, Olson MF: Rho GTPase signalling pathways in the morphological changes associated with apoptosis. Cell Death Differ 2002, 9:493-504

41. Fritz G, Just I, Kaina B: Rho GTPases are over-expressed in human tumors. Int J Cancer 1999, 81:682-687.

42. Etienne-Manneville S: Cdc42-the centre of polarity. J Cell Sci 2004, 117:1291-1300.

43. Tocque B, Delumeau I, Parker F, Maurier F, Multon MC, Schweighoffer F: Ras-GTPase activating protein (GAP): a putative effector for Ras. Cell Signal 1997, 9:153-158

44. Wang $\mathrm{W}$, Eddy $\mathrm{R}$, Condeelis J: The cofilin pathway in breast cancer invasion and metastasis. Nat Rev Cancer 2007, 7:429-440

45. Fernandez-Hernando C, Suarez Y, Lasuncion MA: Lovastatin-induced PC-12 cell differentiation is associated with RhoA/RhoA kinase pathway inactivation. Mol Cell Neurosci 2005, 29:591-602.

46. Luo Y, Hurwitz J, Massague J: Cell-cycle inhibition by independent CDK and PCNA binding domains in p21Cip1. Nature 1995, 375:159-161.

47. Gehen SC, Vitiello PF, Bambara RA, Keng PC, O'Reilly MA: Downregulation of PCNA potentiates p21-mediated growth inhibition in response to hyperoxia. Am J Physiol Lung Cell Mol Physiol 2007, 292:L716-724.

48. Sanchez CA, Rodriguez E, Varela E, Zapata E, Paez A, Masso FA, Montano LF, Lopez-Marure R: Statin-induced inhibition of MCF-7 breast cancer cell proliferation is related to cell cycle arrest and apoptotic and necrotic cell death mediated by an enhanced oxidative stress. Cancer Invest 2008, 1 .

49. Sanchez CA, Rodriguez E, Varela E, Zapata E, Paez A, Masso FA, Montano LF, Loopez-Marure R: Statin-induced inhibition of MCF-7 breast cancer cell proliferation is related to cell cycle arrest and apoptotic and necrotic cell death mediated by an enhanced oxidative stress. Cancer Invest 2008, 26:698-707.

50. Sivaprasad U, Abbas T, Dutta A: Differential efficacy of 3-hydroxy-3methylglutaryl CoA reductase inhibitors on the cell cycle of prostate cancer cells. Mol Cancer Ther 2006, 5:2310-2316.

51. Cortez D, Glick G, Elledge SJ: Minichromosome maintenance proteins are direct targets of the ATM and ATR checkpoint kinases. Proc Natl Acad Sci USA 2004, 101:10078-10083.

52. Chang IY, Jin M, Yoon SP, Youn CK, Yoon Y, Moon SP, Hyun JW, Jun JY, You HJ: Senescence-dependent MutS alpha dysfunction attenuates mismatch repair. Mol Cancer Res 2008, 6:978-989.

53. Montesano Gesualdi N, Chirico G, Pirozzi G, Costantino E, Landriscina M, Esposito F: Tumor necrosis factor-associated protein 1 (TRAP-1) protects cells from oxidative stress and apoptosis. Stress 2007, 10:342-350.

54. Song JY, Lim JW, Kim H, Morio T, Kim KH: Oxidative stress induces nuclear loss of DNA repair proteins Ku70 and Ku80 and apoptosis in pancreatic acinar AR42J cells. J Biol Chem 2003, 278:36676-36687.

55. Warburg O: On the origin of cancer cells. Science 1956, 123:309-314.

56. Plas DR, Thompson CB: Akt-dependent transformation: there is more to growth than just surviving. Oncogene 2005, 24:7435-7442.

57. Li X, Lin G, Wu B, Zhou X, Zhou K: Overexpression of PTEN induces cell growth arrest and apoptosis in human breast cancer ZR-75-1 cells. Acta Biochim Biophys Sin (Shanghai) 2007, 39:745-750.
58. Cantley LC, Neel BG: New insights into tumor suppression: PTEN suppresses tumor formation by restraining the phosphoinositide 3kinase/AKT pathway. Proc Natl Acad Sci USA 1999, 96:4240-4245.

59. Mensah K, Mocanu MM, Yellon DM: Failure to protect the myocardium against ischemia/reperfusion injury after chronic atorvastatin treatment is recaptured by acute atorvastatin treatment: a potential role for phosphatase and tensin homolog deleted on chromosome ten? J Am Coll Cardiol 2005, 45:1287-1291.

60. Teresi RE, Shaiu CW, Chen CS, Chatterjee VK, Waite KA, Eng C: Increased PTEN expression due to transcriptional activation of PPARgamma by Lovastatin and Rosiglitazone. Int J Cancer 2006, 118:2390-2398.

61. Teresi RE, Planchon SM, Waite KA, Eng C: Regulation of the PTEN promoter by statins and SREBP. Hum Mol Genet 2008, 17:919-928.

62. Kim RH, Peters $M$, Jang $Y$, Shi W, Pintilie M, Fletcher GC, DeLuca C, Liepa J, Zhou L, Snow B, Binari RC, Manoukian AS, Bray MR, Liu FF, Tsao MS, Mak TW: DJ-1, a novel regulator of the tumor suppressor PTEN. Cancer Cell 2005, 7:263-273.

63. Davidson B, Hadar R, Schlossberg A, Sternlicht T, Slipicevic A, Skrede M, Risberg B, Florenes VA, Kopolovic J, Reich R: Expression and clinical role of DJ-1, a negative regulator of PTEN, in ovarian carcinoma. Hum Pathol 2008, 39:87-95.

64. Nagakubo D, Taira T, Kitaura H, Ikeda M, Tamai K, Iguchi-Ariga SM, Ariga H: DJ-1, a novel oncogene which transforms mouse NIH3T3 cells in cooperation with ras. Biochem Biophys Res Commun 1997, 231:509-513.

65. Bandyopadhyay S, Pai SK, Hirota S, Hosobe S, Tsukada T, Miura K, Takano Y, Saito K, Commes T, Piquemal D, Watabe M, Gross S, Wang Y, Huggenvik J, Watabe K: PTEN up-regulates the tumor metastasis suppressor gene Drg1 in prostate and breast cancer. Cancer Res 2004, 64:7655-7660.

66. Baum CL, Reschly EJ, Gayen AK, Groh ME, Schadick K: Sterol carrier protein-2 overexpression enhances sterol cycling and inhibits cholesterol ester synthesis and high density lipoprotein cholesterol secretion. J Biol Chem 1997, 272:6490-6498.

67. Frolov A, Miller K, Billheimer JT, Cho TH, Schroeder F: Lipid specificity and location of the sterol carrier protein-2 fatty acid-binding site: a fluorescence displacement and energy transfer study. Lipids 1997, 32:1201-1209.

\section{doi:10.1186/bcr2485}

Cite this article as: Klawitter et al.: Effects of lovastatin on breast cancer cells: a proteo-metabonomic study. Breast Cancer Research 2010 12:R16.

\section{Submit your next manuscript to BioMed Central and take full advantage of:}

- Convenient online submission

- Thorough peer review

- No space constraints or color figure charges

- Immediate publication on acceptance

- Inclusion in PubMed, CAS, Scopus and Google Scholar

- Research which is freely available for redistribution

Submit your manuscript at www.biomedcentral com/submit
C Biomed Central 